\title{
Article
}

\section{Rethinking the Puzzle of Escalating Penalties for Repeat Offenders}

\author{
David A. Dana ${ }^{\dagger}$
}

\author{
CONTENTS
}

I. INTRODUCTION

II. DECLINING PENALTIES FOR REPEAT OFFENDERS AS "OPTIMAL" DETERRENTS: THE SIGNIFICANCE OF ESCALATING PROBABILITIES OF DETECTION

A. Optimal Deterrence as an Evaluative Baseline ...........................740

B. Escalation in Probabilities of Detection .....................................742

1. Linking Known Violations to Unknown Perpetrators.............744

2. Detecting Unknown Violations .............................................746

C. Objections to the Empirical Claim Regarding Probabilities

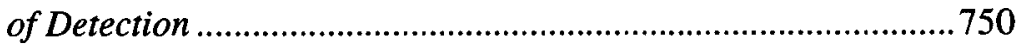

D. The Significance of Escalating Probabilities of Detection for Optimal Penalty Levels .............................................................754

1. Conserving Enforcement Costs.............................................755

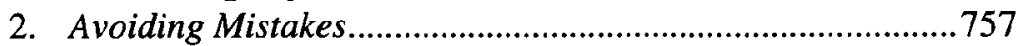

$\dagger$ Professor of Law, Northwestem University School of Law; Faculty Fellow, Institute for Policy Research, Northwestern University. I have greatly benefited from the comments of participants at the University of Michigan, Northwestern, Tel Aviv University, and University of Toronto faculty workshops. Special thanks for helpful comments are due to Omri Ben-Shahar, Lisa Bernstein, George Cohen, Hanoch Dagan, Shari Diamond, Jim Krier, Daryl Levinson, Saul Levmore, Richard McAdams, Julie Schrager, and Omri Yadlin. 
III. HeURistic Biases and PenAlty Escalation Based on

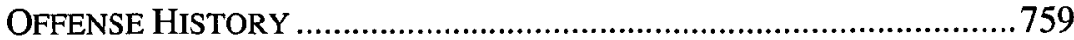

A. Salience/Availability and Optimism Biases.................................759

B. A Simple Two Time Period Model................................................763

C. Moving Beyond a Two-Period Model .........................................765

D. Moving Beyond Simple Record/No Record Comparisons.............768

E. A (Very) Modest Step Toward Empirical Substantiation ...............770

IV. DECLINING SOCIAL SANCTIONS AS AN EXPLANATION OF ESCALATING LEGAL SANCTIONS .....................................................772

V. PENALty EsCALATION, WrongfulnESS, AND COMPLIANCE............776

A. The Message of Penalty Escalation and Alternative

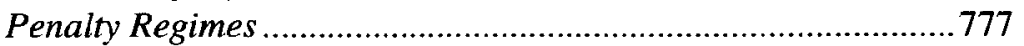

B. The Distinction Between Reinforcing and Creating a Perception of Wrongfulness

C. A Normative Evaluation of Penalty Escalation as a Means of Reinforcing and Creating Perceptions of Wrongfulness..............781

VI. CONCLUSION 


\section{INTRODUCTION}

The legal system punishes repeat offenders more severely than nonrepeat offenders. Second-time offenders receive more severe punishment than first-time offenders; repeat offenders with many previous offenses receive more severe punishment than repeat offenders with a few previous offenses. Indeed, the general principle of escalating penalties based on offense history is so widely accepted that it strikes most people as simple common sense. The principle is embedded in formal federal, state, and administrative codes and in the enforcement norms of prosecutors and government officials at all levels of government.'

Penalty escalation based on offense history, moreover, is not limited to any particular kinds of offenses. Escalation certainly characterizes the treatment of "traditional" criminal offenses, such as theft, assault, and murder. ${ }^{2}$ But escalation also characterizes the treatment of regulatory or "public welfare" offenses, such as violations of environmental, worker safety, health, immigration, and labor regulations. ${ }^{3}$ Thus, the Inspector

1. Moshe Burnovski \& Zvi Safra, Deterrence Effects of Sequential Punishment Policies: Should Repeat Offenders Be More Severely Punished?, 14 INT'L REV. L. \& ECON. 341, 341 (1994) ("The concept of punishing repeat offenders more severely is strongly rooted. . . It has been accepted as a major factor underlying the statutory punishment policy in the United States and other countries."); C.Y. Cyrus Chu et al., Punishing Repeat Offenders More Severely, 20 INT'L REV. L. \& ECON. 127, 127 (2000) ("That repeat offenders are punished more severely ... is a generally accepted practice ...."); A. Mitchell Polinsky \& Steven Shavell, On Offense History and the Theory of Deterrence, 18 INT'L REV. L. \& ECON. 305, 305 (1998) ("In practice, the law often sanctions repeat offenders more severely ....").

2. The three-strikes-and-you're-out statutes in California and elsewhere are recent dramatic examples of such penalty escalation. See Mark Mauer, Why Are Tough on Crime Policies So Popular?, 1 STAN. L. \& POL'Y REV. 9 (1999) (reviewing and criticizing three-strikes statutes); Michael Vitiello, Three Strikes: Can We Return to Rationality?, 87 J. CRIM. L. \& CRIMINOLOGY 395 (1997) (reviewing the adoption and operation of the California three-strikes statutes); see also U.S. SENTENCING GUIDELINES MANUAL 289-308 (1998) (describing the relevance of past criminal history and civil adjudications to federal criminal sentencing).

3. Many federal and state statutes and regulations provide for higher maximum monetary and nonmonetary penalties for repeat regulatory offenses. See, e.g., Occupational Safety and Health Act, 29 U.S.C. $\$ 666$ (a) (1994) (providing for up to ten times the base penalty for repeat offenses); Clean Water Act, 33 U.S.C. § 1319(c)(1), (2) (1994) (providing for double penalties for repeat offenses); Clean Air Act, 42 U.S.C. § 7413(c)(1) (1994) (providing for double penalties for repeat offenses); Comprehensive Environmental Response, Compensation and Liability Act, id. \$ 9609(b)(5), (c) (providing for treble penalties for repeat offenses); Virginia Pesticide Control Act, VA. CODE ANN. \$ 3.1-249.70 (Michie 1994) (providing for quadruple penalties for repeat violations); Control of Employment of Aliens, 8 C.F.R. $\$ 274 \mathrm{a} .10$ (2000) (providing for sharply escalating fines for repeat offenses); ADVISORY WORKING GROUP ON ENVTL. OFFENSES, U.S. SENTENCING COMM'N, REPORT FROM ADVISORY GROUP ON ENVIRONMENTAL SANCTIONS 1315 (1993), at http://www.ussc.gov/environ.pdf (recommending upward adjustments in criminal sanctions based on past criminal, civil, and/or administrative adjudications); U.S. SENTENCING COMM'N, SUPPLEMENTARY REPORT ON SENTENCING GUIDELINES FOR ORGANIZATIONS 20 (1991) (reviewing data indicating that organizations receive higher criminal sanctions for repeat offenses); Baker \& Daniels, Doubling the Fun: IOSHA Penalties for Repeated Violations, 7 No. 1 IND. ENVTL. COMPLIANCE UPDATE (1997) (describing escalation in penalties under state statutes). 
General of the federal Environmental Protection Agency recently explained that

[O]ne generally agreed upon enforcement concept is that of escalating enforcement actions for repeat violations. For instance, a violator may initially be required to comply with an administrative order or be assessed a relatively small monetary penalty. If these actions do not bring about compliance, the enforcement actions may be escalated to civil or criminal judicial actions and progressively higher monetary penalties. ${ }^{4}$

For economists and law-and-economics scholars, however, the principle of escalating penalties based on offense history is puzzling. In the standard economic model, the purpose of penalties is to deter conduct that creates greater social costs than benefits; where the system of penalties is calibrated to produce "optimal deterrence," offenses that produce net social costs will be deterred while offenses that produce net social benefits will go undeterred. Within this paradigm, the key factor in assessing the optimal penalty for a given offense is the social harm that will result from the offense. But the social harm from a given offense would seem to have nothing to do with the offense history of the offender; the illegal discharge of waste into the ocean causes as much social harm when the discharging company is a first-time offender as when it has a long history of such

4. Enforcement of Environmental Laws: Hearing Before the Senate Comm. on Env't and Pub. Works, 105th Cong. 186 (1997) (statement of Nikki L. Tinsley, Acting Inspector General, U.S. Environmental Protection Agency) [hereinafter Tinsley]; see also Gregory A. Bibler, Counseling the Client on Environmental Crimes, 37 No. 5 PRAC. LAw. 37, 54 (1991) (stating that "repeated [noncriminal] penalties for similar infractions" provoke regulators "to refer a corporation or its officers for criminal investigation"). The pattern of escalation Tinsley describes-from administrative to civil penalties, from civil penalties to criminal penalties-also appears outside the environmental context. E.g., Fraud in the Micro-Capital Markets Including Penny Stock Fraud: Hearing Before the Permanent Subcomm. on Investigations of the Senate Comm. on Governmental Affairs, 105th Cong. 262 (1997) [hereinafter Fraud in the Micro-Capital Markets] (statement of Barry R. Goldsmith, Executive Vice President, NASD Regulation, Inc.) (reporting "the NASD's belief that a primary objective of its disciplinary process is to deter future violations by imposing progressively escalating sanctions on repeat offenders," including referral for criminal prosecution); Lawrence J. Zweifach, Recent Trends in the Criminal Prosecution of Federal Securities Law Violations, in SECURITIES LITIGATION 353, 356 (PLI Corporate Law \& Practice Course, Handbook Series No. B0-00DM, 1999) (reporting that the likelihood of a criminal referral by the SEC is higher if the subject is a repeat offender). Of course, regulators do not always employ escalating penalties in practice. The absence of escalation, however, often provokes calls for reform. E.g., Oversight of the Office of Motor Carriers: Hearing Before the House Comm. on Transp. and Infrastructure, 106th Cong. 66 (1999) (statement of Kenneth M. Mead, Inspector General, Office of Motor Carriers, U.S. Department of Transportation) (stating the Department of Transportation's commitment to increase the penalties imposed upon repeat offenders); Tinsley, supra (praising state efforts to correct their failures to escalate penalties for environmental noncompliance); Nat'l Comm'n on Restructuring the Internal Revenue Serv., $A$ Vision for a New IRS, 123 Daily Tax Rep. (BNA) L-5 (June 26, 1997) (reporting the recommendation of a blue-ribbon commission that the IRS "use technology to tailor compliance programs that target repeat offenders"). 
offenses. Thus, standard economic analysis would seem to suggest that, contrary to actual practice, penalties should not escalate based on offense history.

A central claim of this Article is that the phenomenon of escalating penalties based on offense history presents an even greater puzzle from an economic perspective than has been previously recognized. The economic model of optimal deterrence actually supports declining penalties based on offense history for some categories of offenses, rather than nonescalating or escalating penalties. Contrary to the assumptions of the existing literature, the probability that a person or corporation will be detected committing a violation correlates with offense history: In other words, holding all other variables constant, people and entities with "records" have a higher probability of having their offenses detected than people and entities without records. Moreover, people and entities with records assume higher risks of audits for previously undetected past offenses when they commit new offenses. Because previous violators face higher probabilities of detection, conventional economic theory dictates lower penalties ${ }^{5}$ for previous offenders than for those with clean records. The case for declining penalties based on offense history, however, is not uniformly strong. The case is strongest in the context of regulatory offenses, such as violations of environmental, safety, and labor regulations, and weakest in the context of the core traditional criminal offenses, such as assault and murder. ${ }^{6}$

The remainder of the Article is a three-part exploration of the question of whether, by broadening the analytic focus beyond conventional economics, penalty escalation might be explained on the basis of offense history. First, the Article explores whether behavioral economics and cognitive psychology can help reconcile the theory of optimal deterrence with the principle of escalating penalties based on offense history. The opposite turns out to be true. A central contribution of the behavioral economics literature has been the identification of certain heuristic biases that help to explain why people act in ways that seem to deviate from the predictions of economic models that assume complete rationality in decisionmaking. The literature regarding salience bias-the bias toward exclusive or over-consideration of personal, recent, vivid experiencesuggests that individuals who have recently been detected and punished for a violation should face reduced penalties because their recent detection and punishment experience will bolster their fears of future detection and punishment. The behavioral economics literature also suggests that individuals will be overoptimistic about their chances of avoiding detection

5. That is, lower penalties are "efficient." By an efficient penalty, I mean a penalty calculated to deter only conduct producing greater net social costs than benefits. See infra Section II.A.

6. See infra Subsection II.D.1. 
of wrongdoing until they are actually caught. This analysis suggests, once again, that, in order to achieve optimal deterrence, our legal system should provide for less severe penalties for repeat offenders than for first-time offenders instead of, as it currently does, reserving the least severe penalties for the latter group.

Second, the Article explores the possible significance of social, extralegal sanctions in explaining the phenomenon of escalating legal sanctions based on offense history. The punishment suffered by an individual or entity for any offense is the sum of both social and legal sanctions. For a variety of reasons, social sanctions probably decrease with offense history: The marginal reputational loss from a first conviction for securities fraud is much greater than the marginal reputational loss from a fourth conviction. To the extent this is true, and to the extent that the decline in social sanctions based on offense history merely counteracts the escalation in legal sanctions based on offense history, there may, in fact, be no escalation in aggregate sanctions based on offense history. Escalation in legal sanctions thus may be consistent with economic theory and hence not puzzling because it is part of a regime of nonescalating aggregate sanctions.

The Article also explores whether penalty escalation might be justified as a means for the government to express moral condemnation of legally prohibited conduct. Penalty escalation, particularly the escalation from noncriminal to criminal sanctions, probably helps to create and reinforce popular perceptions that legally prohibited conduct is not merely legally wrong but also morally wrong and should not be engaged in for that very reason (as opposed to reasons based on perceived probabilities of magnitude and certainty of punishment). These perceptions of moral wrongfulness matter, because people sometimes will make compliance decisions based on moral considerations and because it is far more costly for the government to achieve compliance based on fear of punishment (as that necessitates investments in enforcement resources such as police, inspectors, courts, etc.). In other words, penalty escalation, through its expressive power to shape popular perceptions of moral wrongfulness, allows society to conserve its resources for investments other than law enforcement.

The answer to the question whether economics can explain penalty escalation, then, is quite complex. Two previously ignored factorsescalating probabilities of detection for repeat offenders and salience and optimism biases--suggest that an optimal penalty regime should employ declining, rather than escalating, penalties, at least in some contexts. These factors indicate that, for example, a landowner who repeatedly violates prohibitions against filling wetlands should receive a lower sanction than a first-time violator. At the same time, two other previously ignored factorsthe interplay of legal and social sanctions and the power of escalation to 
encourage compliance by expressing moral condemnation-support penalty escalation notwithstanding the presence of escalating probabilities of detection and cognitive biases. This Article thus does not definitively solve the puzzle of escalating penalties for repeat offenders, but it does enrich an understanding of its complexity and point to new avenues for theoretical and empirical research.

Part II presents the standard account of optimal deterrence and explains why, given escalating probabilities of detection, optimal deterrence would seem to dictate declining penalties for repeat offenders. Parts III and IV explore the relevance of cognitive biases and extralegal sanctions, respectively. Finally, Part $\mathrm{V}$ develops the argument that escalating penalties serve an expressive function as a means of labeling certain conduct as not merely legally, but also morally, wrong.

\section{DECLINING PENALTIES FOR REPEAT OFFENDERS AS "OPTTMAL" DETERRENTS: THE SIGNIFICANCE OF ESCALATING PROBABILITIES OF DETECTION}

This Part first explains the concept of optimal deterrence and its central role in the economics literature regarding public enforcement and sanctions. The Part then explains why, on average, probabilities of detection ${ }^{7}$ increase with an individual or entity's number of previously detected offenses. This fact, which is not addressed in the current literature, ${ }^{8}$ calls into question previous efforts to explain penalty escalation based on offense history as a practice consistent with the optimal-deterrence model employed in conventional economics. As explained below, escalation in probabilities of detection is likely to be most significant in the context of regulatory offenses, where violations often remain hidden in the absence of government audits. Finally, this Part assesses empirical and theoretical arguments that might weigh in favor of escalating penalties notwithstanding the existence of escalating probabilities of detection.

7. I am using the term "probability of detection" as a shorthand for the probability that a violation will be detected, formally recognized, and punished by the government. See Richard Craswell, Deterrence and Damages: The Multiplier Principle and Its Altematives, 97 MiCH. L. REV. 2185, 2212 (1999) (emphasizing that deterrent effects of penalties depend not only on probabilities of detection but also on probabilities of prosecution, which are typically less than $100 \%$ ).

8. Professors Polinsky and Rubinfeld do note the possibility that probabilities of detection may decrease or increase based on offense history, but they base their analysis on an assumption of constancy in probabilities of detection. See A. Mitchell Polinsky \& Daniel L. Rubinfeld, $A$ Model of Optimal Fines for Repeat Offenders, 46 J. PUB. ECON. 291, 303 (1991). 


\section{A. Optimal Deterrence as an Evaluative Baseline}

The conventional economic model of deterrence assumes that individuals (and by extension, the entities they compose) have preferences and tastes independent of the content of legal prohibitions. Individuals will comply with a legal prohibition if the expected penalty-the expected cost to them of the violation-will exceed the gain they expect to derive from the violation. Two variables are relevant in assessing expected penalties: the magnitude of the formal sanction if the violation is detected $(p)$ and the probability of detection ( $p d e t$ ), as perceived by the prospective violator. For example, where an individual knows that the fine for a traffic violation is $\$ 100$ and he or she perceives a $10 \%$ probability that a violation will be detected, he or she will calculate an expected penalty of $100 \times 0.1$ or $\$ 10$. . $^{9}$ If the expected benefits to the individual of the violation exceed $\$ 10$, he or she presumably will violate the law.

In this model, an expected penalty is optimal-in the sense that it will produce the optimal level of compliance with law-when it equals the harm or cost that the violation will cause to society. Optimal expected penalties produce optimal deterrence-that is, deterrence of those prospective violations and only those prospective violations for which the resulting harm to society $(h)$ would exceed the resulting gain or benefit to the violator. More specifically, an optimal expected penalty should equal the harm to society of the violation, so that the prospective offender will proceed with the violation only if the gain from doing so (which is also a societal welfare gain) exceeds the social harm that will result from the violation.

In formal terms, assume that pdet represents the probability of detection, $s$ represents the sanction for a violation, and $h$ represents the harm from a violation. Then the violator's expected penalty would equal $(p d e t)(s)$, and the expected penalty would be optimal when it equaled $h$. Thus the optimal sanction for a violation, $s$, is $h / p d e t$. For example, if the harm from a violation will be $\$ 100$, and the probability of detection is 0.1 , the optimal formal sanction is $\$ 100 / 0.1$ or $\$ 1000$. With various permutations and refinements, the optimal-deterrence model briefly

9. What is important, with respect to predicting behavior, is that the prospective violator perceive the probability of detection as $10 \%$ whether or not that is the actual probability. The perceptual deterrence literature rightly emphasizes the need to factor misperceptions of probabilities into models of the deterrent power of penalties. For a good overview, see Daniel S. Nagin, Criminal Deterrence Research at the Outset of the Twenty-First Century, 23 CRIME \& JUST. 1, 5 (1998), which states, "The perceptual deterrence literature was spawned by the recognition that deterrence is ultimately a perceptual phenomenon." 
outlined here has remained dominant in the law-and-economics literature for several decades. ${ }^{10}$

Two basic but critical points bear note regarding the optimal-deterrence model. First, the amount of gain a prospective violator will garner from a violation is irrelevant to the task of setting an optimal sanction. The optimal sanction depends on the probability of detection and harm from the violation, both of which are unrelated to the violator's gain from the violation. The prospective violator's gain from a violation is relevant, of course, to the question of whether a given prospective violator will break the law and assume the risk of the optimal sanction, but, axiomatically, given the assumptions of the model, if sanctions are optimal and the prospective violator breaks the law, that fact demonstrates the social efficiency of the violation; if the prospective violator foregoes a violation, that fact demonstrates the social efficiency of compliance with law.

Second, in the optimal-deterrence model, the goal is not to achieve complete or total or maximal deterrence but rather only deterrence of socially inefficient violations. Indeed, the model assumes that not all violations of all kinds are inefficient and thus, in a sense, it assumes some violations are a good thing. People in ordinary discourse often invoke the word "deterrence" in discussing law and policy matters, but when they do, they generally speak as if the accepted goal of our legal system is to deter all violations of law. ${ }^{11}$ Optimal-deterrence theory rejects that goal, except with regard to those categories of offenses that entail so much social harm that the optimal deterrence-level is (at least putting enforcement costs aside) maximal deterrence in every case. Violent crimes invariably entail greater social costs than benefits, both because of the severity of the costs borne by the victims and because of the indirect costs imposed on society in the form of fear, insecurity, and investment in protection. It is less obvious that all instances of so-called victimless crimes (drug possession, moral offenses)

10. The optimal-deterrence model has roots at least as far back as the eighteenth century. See Gary S. Becker, Crime and Punishment: An Economic Approach, 76 J. POL. ECON. 169, 209 (1968) (explaining that "two important contributors to criminology during the eighteenth and nineteenth centuries, Beccaria and Bentham, explicitly applied an economic calculus"). There are a number of examples of recent scholarship applying and refining the optimal-deterrence model. See Omri Ben-Shahar, Playing Without a Rulebook: Optimal Enforcement When Individuals Learn the Penalty Only by Committing the Crime, 17 INT'L REV. L. \& ECON. 409 (1997) (developing the optimal-deterrence model without the assumption of perfect information); Daniel R. Fischel \& Alan O. Sykes, Corporate Crime, 25 J. LEGAL STUD. 319 (1996) (criticizing criminalization of corporate conduct as inconsistent with the optimal-deterrence model); A. Mitchell Polinsky \& Steven Shavell, Enforcement Costs and the Optimal Magnitude and Probability of Fines, 35 J.L. \& ECON. 133 (1992) (demonstrating that the optimal-deterrence model may dictate lower penalties once enforcement costs are included in the societal calculus).

11. Cf. Cass R. Sunstein et al., Do People Want Optimal Deterrence?, 29 J. Legal STUD. 237, 239 (2000) (suggesting that lay people, such as jurors, do not believe that punishments should depend on probabilities of detection and, in that sense, do not believe in optimal deterrence as a policy objective). 
and property crime (theft, trespass) are inefficient, although many would take this position. ${ }^{12}$ With respect to offenses based on public welfare regulations, such as violations of environmental, safety, and labor regulations, no clear consensus exists as to whether maximal deterrence is optimal deterrence. To take one example. federal law provides for administrative, civil, and even criminal penalties for the unauthorized filling of wetlands. But some would argue that filling wetlands does not always-or even almost always-entail greater social costs than benefits. According to this view, the optimal level of deterrence of wetland regulations is significantly less than maximal deterrence. ${ }^{13}$

\section{B. Escalation in Probabilities of Detection}

For law-and-economics scholars, the practice of escalating penalties for repeat offenders has been puzzling, because these scholars start with the assumption that the harm from an offense and the probability of detection are unrelated to the presence or absence of previously detected offenses, and that the optimal penalty, $h / p d e t$, should therefore be the same for all offenders without regard to their previous record. These scholars thus frame their task as explaining why, even though constant penalties would at first blush seem to be optimal, escalating penalties in some cases may nonetheless be optimal. This approach unduly simplifies the puzzle presented by escalating penalties because, in many contexts, the more appropriate assumption is that the probability of detection increases with the number of past detected offenses. For this reason, the arguably optimal penalty practice would be declining penalties based on offense history. For example, imagine that the optimal penalty for violating a pollution standard is $\$ 200$ because the harm caused thereby is the equivalent of $\$ 200$. The pdet for an offender without a record is 0.2 , and the pdet for an offender with one past detected offense is 0.3 . In that case, the optimal sanction for a first offense would be $\$ 200 / 0.2$ or $\$ 1000$; the optimal sanction for a second-time offender would be much lower, $\$ 200 / 0.3$ or roughly $\$ 667$.

The question whether probabilities of detection escalate is ultimately an empirical matter, but not a matter easily subject to study. Because offenders

12. See, e.g., Richard L. Hasen \& Richard H. McAdams, The Surprisingly Complex Case Against Theft, 17 INT'L REV. L. \& ECON. 367 (1997) (concluding that theft is invariably inefficient, but arguing that the demonstration of this inefficiency is not straightforward).

13. For good discussions of the controversy surrounding wetlands regulation and enforcement, see Kathleen F. Brickey, Wetlands Reform and the Criminal Enforcement Record: A Cautionary Tale, 76 WASH. U. L.Q. 71 (1998); and David M. Forman, Economic Development Versus Environmental Protection: Executive Oversight and Judicial Review of Wetland Policy, 15 U. HAW. L. REV. 23 (1993). For a thoughtful discussion of the relevance of the optimaldeterrence paradigm to endangered species regulation and analysis, see Barton $\mathrm{H}$. Thompson, Jr., People or Prairie Chickens: The Uncertain Search for Optimal Biodiversity, 51 STAN. L. REV. 1127 (1999). 
are reluctant to provide candid information regarding their undetected violations, researchers face huge obstacles in developing any comparative assessments of the success of different groups of offenders in evading detection. As discussed below, however, we do know that the experience of detecting and prosecuting a violator provides government enforcement agencies with information that, as a logical matter, should assist those agencies in detecting any future violations by the violator. Because the quality and extent of the government's information regarding an individual or entity increase with the number of previously detected violations, the probability of detection for an individual or entity's next violation should depend in part on offense history.

As a preliminary matter, even before considering the kinds of information the government may amass through the detection of violations, it may be helpful to distinguish between two sorts of challenges government agencies face in detecting violations of law. The first challenge is that of linking an obvious, reported violation of law to a specific, as yet unknown perpetrator. Many offenses, particularly traditional criminal offenses, have victims who understand themselves to be victims and hence are likely to report the fact that they suffered from someone else's lawbreaking. All violent crime probably fits this category; theft and fraud do too, at least in that subset of cases where the monetary loss (and its illegitimacy) comes to the attention of the victims. Violation of laws prohibiting destruction or damage to property (for example, antivandalism and antidumping laws) also falls within this category, again, at least, where the property damage is visible to the owner. In some cases, the victim will know the identity of the perpetrator, but in other cases will not. Moreover, in many cases, the victim will lack proof of identity that would meet the standards of criminal or even civil law. Finally, even where the victim has strong evidence of the identity of the immediate perpetrator (for example, the robber who is captured by the homeowner during the crime), the victim will probably lack evidence of the identity of those who may have conspired with the immediate perpetrator (for example, other members of the burglary ring, or the fence for the stolen goods). For violations of law such as robbery to be punished, the government must discern and prove who is responsible, but the existence of the violation itself entails no need for detective work.

In other contexts, the challenge for the government lies in detecting the very existence of a violation of law that in the absence of government investigation might never come to light. Some legal prohibitions-for example, those embodied in environmental and worker safety lawsaddress conduct that creates a risk of harm but that may never actually result in harm, or that may result in harm that remains latent too long or is too subtle or too diffuse to be noticed by the victims for years, if ever. 
Moreover, the possible victims of many offenses are either too large and diffuse a group to engage in organized detection efforts-for example, the population of an entire region suffering from diverse health effects due to pollution control violations-or too resource-poor to engage in such efforts. In settings where there are no identifiable, self-aware, well-informed, and unintimidated victims to report a violation-the setting of many regulatory or public welfare offenses-a critical aspect of public enforcement is the detection of the violation itself.

These two challenges for government enforcement of law-the challenge of linking obvious, known violations to unknown violators and the challenge of detecting hidden or subtle violations-raise distinct questions for the relationship between pdet and offense history. Does the fact that an individual has a record of committing obvious, known violations-say, robbery-increase the likelihood that the government will successfully link that individual to any future armed robberies she may commit? Does the fact that an individual or entity has a record of committing hidden or subtle violations-say, violations of environmental and labor laws-increase the likelihood that the government will uncover future violations on the part of the individual or entity? The answer to both questions is generally yes, in substantial part because the fact that an individual or entity is known to have violated a certain law informs the government that, at least as compared to the rest of the general population, the individual or entity has a greater than average "propensity" to violate that law in the future. ${ }^{14}$

\section{Linking Known Violations to Unknown Perpetrators}

Propensity-related information can, and does, help government agencies to focus their search on the parties who are responsible for visible,

14. The successful past prosecution of an individual or entity provides government enforcement officials with three sorts of information that might be categorized as propensityrelated information. The three sorts of information are: (1) information regarding the individual or entity's opportunities to commit certain offenses; (2) information regarding the individual or entity's inclination to exploit those opportunities by breaking the law; and (3) information regarding the individual or entity's habitual methods, if any-the modus operandi-in committing certain offenses. Propensity-related evidence can be admitted in court only under limited circumstances (albeit less limited than most people realize) as proof that an individual or entity is guilty of committing an offense. As many commentators have noted, however, the reason that our legal system limits the use of propensity evidence to establish guilt for a given offense is not that such evidence is widely thought to lack probative value. Quite the contrary: Evidence of past bad conduct is generally regarded as so predictive of future bad conduct that the legal system limits its admissibility out of fear that triers of fact will focus disproportionately upon such evidence in determining guilt or innocence. See Roger C. Park, Character at the Crossroads, 49 HASTINGS L.J. 717, 721 (1998) ("Common sense ... is the principal basis both for believing character evidence to be probative, and for fearing its prejudicial effect."); Peter Tillers, What Is Wrong with Character Evidence?, 49 HASTINGS L.J. 781, 785 (1998) (discussing the "undue prejudice" rationale for excluding bad character and bad past acts evidence). 
essentially public harms such as theft. Imagine, for example, a burglary in Boston. The crime is reported by the homeowner, and there is a neighbor who saw someone leaving the house. In order to search effectively for the perpetrator, the police need a place to start, and a natural starting place is the population of men and women who previously were caught committing thefts in Boston and thus who, by their conduct, have demonstrated an opportunity and inclination to commit such a crime. The police, therefore, might commence their investigation by asking the witness to describe the person she saw, and then comparing the descriptions to physical profiles and photographs they have in their records regarding previously convicted burglars. If the burglar left fingerprints, they might also check those prints against ones on record that have been collected from previously convicted burglars. If the perpetrator of the current, as yet unsolved crime has a record of prior offenses, then the police may be able to identify him or her quite readily using these standard, straightforward approaches. But if the perpetrator has no record, then the police may reach a dead end with the neighbor's description. In optimal-deterrence terminology, the pdet for the violator with a record is higher than for the violator without a record.

The burglary example highlights an important point about how information collected during past prosecutions assists government agencies in current investigations: While past prosecutions provide the government with helpful information related to the propensity of a subpopulation of possible current offenders, past prosecutions also provide the government with a great deal of non-propensity-related information that may facilitate its efforts to determine whether past offenders are also responsible for current violations. The fingerprints the police have on file do not in and of themselves constitute propensity evidence, but they might be key to proving that the past offender has committed another offense. In the case of individuals, the category of helpful non-propensity-related information gathered in past prosecutions includes not only physical information such as fingerprints, DNA, ${ }^{15}$ and photographs, but also life histories and information regarding family members, friends, business associates, and employers.

In the case of entities such as corporations, the category of helpful nonpropensity-related information may include information regarding corporate

15. The probability of detection of previous offenders may be further increased if proposals are implemented to collect DNA from such offenders and to place the DNA in a law enforcement database. C.J. Chivers, Pataki Presses More DNA Use Against Crime, N.Y. Times, Feb. 24, 2000, at BI (reporting that New York's govemor has proposed legislation that would require every person convicted of a crime to provide a biological sample for a state database); David Weber, Officials Eye Charging Inmates for DNA Testing, BOSTON HERALD, Feb. 28, 2000, at 2 (reporting the former state attomey general's opinion that the state-mandated DNA testing of prison inmates "'could make the difference between solving a serious crime and letting someone literally get away with murder, rape or other heinous offenses"'). 
organization and operating practices, as well as information regarding the identity, background, and responsibilities of officers and employees of the corporation. For example, consider a company that has previously been convicted of illegally dumping certain waste products in a quarry. Local authorities have found evidence of similar dumping at a nearby site, but they have no direct evidence of who might be responsible. If in the previous prosecution the police learned where the company routinely stores its trucks and the identity, background, and possible willingness to cooperate of the drivers employed by the company, that non-propensity-related information might allow the government to launch a focused, speedy investigation that would deprive the company's managers of time to cover their tracks adequately. ${ }^{16}$

\section{Detecting Unknown Violations}

The previous examples pertain to government efforts to link visible, essentially public violations to unknown perpetrators, but propensity- and non-propensity-related information gleaned from past prosecutions also can, and does, help government agencies in ferreting out nonobvious, nonpublic violations of law. Indeed, because detection of these sorts of violations depends so critically on the government's choice of investigatory targets, and because the government's choice of those targets is so often guided by offense history, the correlation between probability of detection and offense history may be stronger in the context of hidden, nonobvious violations than it is in the context of essentially public, obvious violations.

As a general matter, government agencies detect nonobvious, nonpublic violations of law by investigating an individual's or entity's compliance with law without knowing, ex ante, whether there actually has been any violation. One difficult question for government agencies is the selection of entities to audit among the many possible choices: Given constrained government resources, government agencies can audit only a tiny fraction of prospective offenders. ${ }^{17}$ Moreover, agencies necessarily must limit the

16. Another important category of information, which one might call postpunishment tracking information, concerns information that government enforcement agencies collect as a result of tracking systems that are imposed upon (or, in the case of settlements, agreed to by) individuals and entities as part of their punishment for a previous offense. The best-known tracking system is probation, which is a common feature of many criminal plea bargains and sentences. Tracking information can help the government prove its case that a previous offender is responsible for current misconduct: Probation reports, for example, can help police discern the recent whereabouts of a suspect and thus can advance the investigation of whether that suspect could have committed the offense under investigation. JONATHAN SIMON, POOR DISCIPLINE: PAROLE AND THE SOCIAL CONTROL OF THE UNDERCLASS, 1890-1990, at 205-29 (1993) (describing the role of parole in increasing the likelihood of reimprisonment).

17. E.g., Developments in the Law-Nonprofit Corporations, 105 HARV. L. REV. 1578, 1600 (1992) (noting the IRS's limited resources to seek out violations); IRS Enforcement Activities Down, 69 CPA J. 12 (1999) (reporting the low, and declining, audit rates of the IRS); Timothy 
scope of their audits in order to preserve resources: An investigation of General Electric's compliance with federal environmental regulations, for example, could focus on any number of facilities and any number of processes within any given facility, but inspectors invariably must pick and choose where to spend their limited time. Whistleblower tips, usually from disgruntled employees, sometimes assist agencies in determining where and how to target their scarce investigative resources, but such tips often turn out to be mistaken or misguided, so agencies also must grapple with how to choose which tips to investigate (and how much time and money to spend on each investigation). Forced to choose relatively few investigative targets from large populations of prospective lawbreakers, government agencies naturally select those targets who they believe are most likely to be committing violations of law. And as discussed above, a record of past noncompliance provides one of the strongest possible bases for suspecting levels of current noncompliance that exceed that of the general population. ${ }^{18}$

Moreover, because government agencies learn a great deal about how an entity operates in the course of a successful investigation and prosecution, it is easier and thus less expensive for agencies to investigate a past offender for possible current wrongdoing than to investigate an entity with a clean record. Consider, for example, bank regulators who wish to investigate whether thrifts are violating federal regulations for maintaining loan loss reserves. Each thrift has different loan loss reserves practices, document systems, and types of loans. Before even addressing whether a thrift is in compliance with the law, regulators must understand the particulars of the operations of that thrift. In the case of a thrift that has

Stoltzfus Jost \& Sharon L. Davies, The Empire Strikes Back: A Critique of the Backlash Against Fraud and Abuse Enforcement, 51 ALA. L. REv. 239, 279 (1999) (explaining that the "level of auditing and enforcement in federal health care programs is very low"); Anne T. Nichting, OSHA Reform: An Examination of Third Party Audits, 75 CHI.-KENT L. REV. 195, 200 (1999) (explaining that there are only 2400 federal state compliance officers to oversee more than six million regulated workplaces); Clifford Rechtschaffen, Deterrence vs. Cooperation and the Evolving Theory of Environmental Enforcement, 71 S. CAL. L. REV. 1181, 1214 (1998) ("It is certainly true that government resources are constrained.... [E]nforcement agencies have never had sufficient staff to inspect more than a fraction of regulated facilities ....").

18. Similarly, agencies that conduct undercover or sting investigations, such as the FBI units devoted to money laundering and public corruption, must prioritize among possible targets given their limited resources. Moreover, because undercover investigations that successfully detect violations often give rise to claims of entrapment, and because the entrapment defense is inapplicable where the target is shown to have had a predisposition to violate the law, agents are likely to focus upon targets with a readily demonstrable predisposition. One of the easiest ways for the government to establish predisposition is to offer proof of past convictions. E.g., Fred Warren Bennett, From Sorrells to Jacobson: Reflections on Six Decades of Entrapment Law, and Related Defenses, in Federal Court, 27 WAKE FOREST L. REV. 829, 844-45 (1992) (explaining that, in determining the issue of a defendant's predisposition, "[t]he most common and damaging evidence relied upon by the prosecution is the defendant's prior criminal conduct.... [I]ntroducing evidence of the defendant's prior convictions, bad acts or poor character is an established practice when entrapment is claimed ...."). 
previously been investigated and found to have committed violations and been penalized, the regulators will have spent a great deal of time learning about the thrift's operations: Their start-up costs for an investigation of current compliance are thus low. The start-up costs of investigating a previously uninvestigated thrift, or even a thrift that was investigated but not found to have violated the law and hence not intensely focused upon, will generally be higher. ${ }^{19}$ Because past offenders are thought to have a propensity to commit future offenses, and because they are easier to investigate than comparable entities without a record, past offenders present government investigators with a very attractive package: relatively high likelihood of success (in terms of finding wrongdoing) at relatively low costs. ${ }^{20}$

Moreover, it is likely not only that government regulators investigate known past offenders more often, but also that the temporal scope of their investigations of known past offenders is different than it is for investigations of individuals and entities with clean records. As discussed above, the existing literature has wrongly assumed that offense history will have no effect on the probability of the detection of future violations. That same literature also has wrongly assumed, implicitly at least, that offense history has no implications for the extent to which, in the course of investigating suspected recent or current violations of law, government agencies will decide to "dig into the past." But the government is more likely to decide to search the more distant past when the target of investigation has a history of violations than when the target has a clean

19. Postdetection tracking information also may play a role in facilitating some investigations of previous corporate offenders. As part of settlements, corporations sometimes agree to engage in special compliance reporting, institute more systematic internal auditing processes, or implement technological monitors. Kirk S. Jordan \& Joseph E. Murphy, Compliance Programs: What the Government Really Wants, in CORPORATE COMPLIANCE 529, 554 (PLI Corporate Law \& Practice Course, Handbook Series No. B0-00L2, 2000) (discussing the role of audits in settlements with government agencies). Internal audit reports and data from technological monitors can potentially lay out and effectively prove the government's case without requiring any significant expenditure of investigative resources. Thus, a company with an internal auditing/technological monitoring system that commits violations faces a higher $p$ det than a company without such a system.

20 . Note that the relatively low cost of investigating a prior offender could explain why, even if government agencies assume that entities with a record and those without have an equal propensity to break the law, government agencies might investigate the former more often. Imagine, for example, that the SEC is considering whether to investigate certain entities, some of which have prior offenses, and some of which do not. For the reasons stated above, it would cost the agency, in time and actual dollars, about half as much to investigate a prior offender as it would to investigate an entity without a record: The agency thus could investigate six previous offenders for the cost of investigating three entities without a record. If the agency is committed to maximizing the return on its resources-that is, maximizing the amount of lawbreaking detected through use of its limited investigatory budget-then it probably would be sensible, propensity considerations aside, for the agency to investigate the six previous offenders rather than the three clean-record entities. For a thoughtful discussion of what bureaucracies seek to maximize, see generally Daryl J. Levinson, Making Government Pay: Markets, Politics, and the Allocation of Constitutional Costs, 67 U. CHI. L. REV. 345, $380-87$ (2000), which describes the agency relationship between elected officials and bureaucrats. 
record. In other words, a substantial offense history increases the likelihood that detection of a recent or current violation will also trigger detection of previously undetected, past violations. As explained below, this insight provides another basis for the counterintuitive position that optimaldeterrence considerations dictate declining, not escalating, penalties based on offense history.

This argument builds on relatively straightforward propositions. First, individuals or entities that are considering whether to violate a legal prohibition sometimes have previously done so and not been caught. Second, government enforcement agencies generally focus on suspected recent or current violations, because they are more likely to have, or think they will be able readily to develop, adequate information regarding such violations. Reconstructing the distant past is inherently resource-intensive and fraught with the risks of gaps in memory and documentation. Third, because unearthing the distant past is so difficult, government agencies are unlikely to try to do so unless they have some basis for believing there is a high likelihood that they will uncover compelling evidence of violations. Fourth, one of the strongest reasons an agency can have to believe that digging into the past will pay off is evidence that the individual or entity at issue has a strong propensity for lawbreaking, and the best evidence of such a propensity is a record of multiple offenses. The more offenses an individual or entity has on its record, the more officials will attribute a strong lawbreaking propensity to it, and the more likely they are to use the occasion of the investigation and prosecution of a recent or current violation by that individual or entity to search for similar, previously undetected violations.

If these propositions are correct, and if they are understood to be so by prospective offenders, then the expected penalty assessments of prospective offenders will depend on whether (and to what extent) the prospective offenders have previously undetected violations and whether (and to what extent) they have a record of detected violations. Consider, for example, two companies, BlueCo. and GreenCo., both of which have a single previously undetected violation. BlueCo. has a record of one detected violation of pollution control regulations, whereas GreenCo. has a clean record. In assessing an expected penalty for a new violation, both companies will consider the likelihood that this new violation would be detected and the magnitude of the sanction that would be imposed in the event of detection. Each company's expected penalty calculation also must include a component that reflects the likelihood that the government's detection of a new violation will prompt the government to investigate and detect a previously undetected violation. BlueCo. is likely to view this component as larger than GreenCo., because BlueCo. will understand that the government probably will respond to a detected violation by a company 
with a record (like itself) with a more expansive investigation than it would in the case of a company with a clean record. Thus, everything else being equal, BlueCo.'s estimate of its expected penalty for a next violation will be larger than GreenCo.'s estimate of its expected penalty for a next violation.

If that is true, then optimal-deterrence considerations would dictate a lower sanction for BlueCo.'s next violation than for GreenCo.'s next violation. For example, imagine that the harm from a violation by either company is $\$ 200$, and that the probability that its next violation will be detected is 0.2 for both companies. For the reasons stated above, the probability that the detection of its next violation will trigger the detection of a previously undetected violation is higher for BlueCo. than GreenCo.say 0.1 in BlueCo.'s case and only 0.01 in GreenCo.'s case. It follows that for the optimal-deterrence condition to be satisfied-for expected penalty to equal harm-BlueCo. must face a formal sanction of $\$ 909$ for its next violation, whereas GreenCo. must face a formal sanction of $\$ 999 .{ }^{21}$

This result-that lower penalties should be imposed on those with records (BlueCo.) than on those without (GreenCo.) -is more blatant if one also assumes (consistent with the discussion above) that BlueCo. faces a higher probability of detection for its next violation than GreenCo. If, for example, one assumes that the probability of detection of a next violation is 0.4 for BlueCo. but only 0.2 for GreenCo., then optimal-deterrence analysis would suggest that BlueCo. should face a formal sanction of $\$ 455$, whereas GreenCo. should face a much higher formal sanction of $\$ 999 . .^{22}$ In short, both the effect of a record on the probability of detection of future violations and its effect on the probability of detection of previously undetected violations support the conclusion that optimal deterrence requires declining penalties based on offense history.

\section{Objections to the Empirical Claim Regarding Probabilities of Detection}

One possible objection to the preceding analysis is that it assumes that the government learns as a result of its experience successfully prosecuting an individual or entity but does not take into account the possibility that offenders learn as a result of having been detected violating the law. ${ }^{23}$ More

21. For both companies, where $h$ equals the harm from a new violation, $s$ equals the optimal formal sanction, $p_{1}$ equals the probability a new violation will be detected, and $p_{2}$ equals the probability a previously undetected violation also will be detected, $s=h /\left[\left(p_{1}\right)+\left(p_{l}\right)\left(p_{2}\right)\right]$. For BlueCo., $s=200 /[0.2+(0.2)(0.1)]=\$ 909$. For GreenCo., $s=200 /[0.2+(0.2)(0.01)]=\$ 999$.

22. The $\$ 455$ penalty for BlueCo. is derived by dividing 200 by the sum of 0.4 and $(0.4)(0.1)$. The $\$ 999$ penalty for GreenCo. is derived by dividing 200 by the sum of 0.2 and $(0.2)(0.01)$.

23. Violators also may leam from the experience of committing undetected violations. The extent of learning may depend very much on the content. An individual may learn how to commit a burglary faster simply by committing a string of undetected burglaries, and that learning may 
specifically, lawbreakers may learn from their failures-that is, their detection by government authorities-how to be better lawbreakers in the future and hence avoid detection for future violations. At least in theory, if learning by offenders roughly balances learning by government agencies, then pdet for a future violation by a known offender might be the same as pdet for an offender with a clean record even though government agencies track more closely the offender with a record. In practice, however, there is not much basis for believing that offenders learn a great deal in the course of being caught and punished that allows them to outwit government investigators in the future. The government often need not, as a matter of law, and thus does not reveal much information about its investigatory methods in the course of civil or criminal enforcement actions. Moreover, because "the government" is composed of multiple, often-changing institutions and personnel, offenders may have a difficult time discerning whether their particular, relatively few experiences getting caught reveal general, widespread investigatory procedures and processes of the government. ${ }^{24}$

The one thing offenders do clearly learn from the detection and punishment of their conduct, however, is that such conduct is subject to a legal prohibition. Some first-time offenders in some contexts commit their offense unwittingly; this is not true of second-time offenders. The knowledge that one's conduct is subject to a legal prohibition, moreover, may lead one to hide that conduct, thereby lowering one's probability of detection for a next offense. Consider two plant owners: The first simply chooses not to invest the resources needed to know what legal prohibitions apply to her plant, and the second has previously been sanctioned for noncompliance and thus knows which prohibitions apply but chooses to

reduce her future probability of detection for burglaries. By contrast, a company that violates federal and state waste discharge limits without detection probably learns little or nothing that would affect its probability of detection for future violations. It also bears noting that there is an imperfect correspondence between an individual or entity's number of detected violations and its number of undetected violations: Some people caught twice committing a burglary have committed only two burglaries, while others may commit many burglaries without ever being caught.

24. Of course, violators might wrongly assume that they have learned a great deal from their previous failures to evade detection and, to the extent this is so, larger sanctions may be required in the short term to achieve optimal deterrence. Indeed, where the actual pdet is low, it may take quite a long time for violators to be disabused of this assumption. Ben-Shahar, supra note 10, at 417. To my knowledge, there has not been any serious empirical examination of how offenders in different contexts characterize what they have learned from an experience of being successfully prosecuted. The extent of learning may well depend on the punishment for the offense: Prison may provide offenders an opportunity to pool information about modes of avoiding detection, so offenders may learn more from the experience of being detected and imprisoned than they do from the experience of being detected and subjected to monetary penalties. John Braithwaite, A Future Where Punishment Is Marginalized: Realistic or Utopian?, 46 UCLA L. REV. 1727, 1738 (1999) ("Prisons are schools for crime; offenders learn new skills for the illegitimate labor market in prison ...."). 
violate them. Both plants' owners are engaging in a course of conduct that may result in socially harmful violations of law, and they should bear a cost in the form of a penalty. But the legally informed violator may face a lower probability of detection because she knows precisely what is unlawful and thus what she should seek to hide ${ }^{25}$ Thus, for the expected penalty of the legally informed violator and the legally uninformed violator to be equivalent, the formal sanction applicable to the former must be higher than that applicable to the latter, if both plant owners face the same risk of inspection. But, as discussed, the previously detected violator faces a higher risk of inspection, and that higher risk may offset any advantages accrued from knowledge of applicable legal prohibitions. Moreover, after a single detected and punished offense, all prospective violators are on notice of applicable prohibitions, so differential knowledge of such prohibitions cannot account for any differences in probabilities of detection after the first detected offense.

Another possible objection concerns an assumption implicit in the preceding analysis: While the variable pdet is in part a function of offense history, it is not a function of the magnitude of formal sanctions and, further, it is not a function of whether the penalty regime decreases, holds constant, or increases formal sanctions based on offense history. Contrary to this implicit assumption, one might argue that, where penalties escalate based on offense history, government agencies will undertake their enforcement activities with that knowledge. If the escalation is dramatic enough-imagine an extreme case, a $\$ 100$ penalty for a first offense and a $\$ 1$ million penalty for a second-government agents may assume that the escalation is sufficient to temper the propensity for lawbreaking of wouldbe second offenders, so that the government would have no propensityrelated reason to focus its investigatory resources disproportionately upon such past offenders. Thus, where the magnitude of penalties escalates based on offense history, the difference between pdet for a prospective first-time offender and for a prospective second-time offender may not be as significant as the preceding discussion would suggest.

That much may well be true, but it is nonetheless reasonable to assume that pdet will often escalate based on offense history to some significant degree whether or not formal penalties escalate based on offense history. One reason repeat offenders face higher probabilities of detection is that the government possesses valuable, non-propensity-related information regarding those past offenders. Whether or not formal penalties escalate, the

25. This relationship between legal knowledge and pdet, which strikes me as key to evaluating the relationship between legal knowledge and optimal penalty levels, is not directly addressed in Louis Kaplow's otherwise illuminating Optimal Deterrence, Uninformed Individuals, and Acquiring Information About Whether Acts Are Subject to Sanctions, 6 J.L. ECON. \& ORG. 93 (1990). 
police will have the use of fingerprints and similar non-propensity-related information only with regard to prior offenders, and the police presumably will use that information to solve cases. Moreover, even where penalties escalate based on offense history, government agencies reasonably will conclude that prior offenders still have a greater propensity to engage in lawbreaking than the rest of the general population.

Consider, for example, violations of labor and tax laws associated with the hiring of undocumented aliens. One can safely presume that, on average, a party with one past offense is less likely to commit a second offense when penalties escalate for a second offense than when the penalty for a second offense is the same as the penalty for a first offense. But even so, a party with one past offense has demonstrated that it has the opportunity to hire undocumented aliens ${ }^{26}$ and a notable lack of a normative commitment to obey the law. And these two facts suggest he is a more promising target for investigation than the average member of the general population of possible employers, many of whom lack any opportunity to rely on undocumented workers and many of whom are normatively committed to legal compliance regardless of the expected benefits and costs. Indeed, here the proof is in the pudding: Even though our current penalty regime is in fact characterized to a substantial degree by escalating penalties based on offense history, government agencies do allocate a very large share of their investigatory resources to tracking "bad actors"-that is, actors with a record of lawbreaking. ${ }^{27}$

26. Indeed, one strand in the criminology literature stresses opportunities to commit crime as the primary determinant of criminality. See generally Paul Cromwell \& Karen McElrath, Buying Stolen Property: An Opportunity Perspective, 31 J. Res. CRIME \& DELINQ. 295 (1994) (finding that opportunity is a major determinant of an individual's decision to buy stolen goods); Joseph F. Sheley, Critical Elements of Criminal Behavior Explanation, 24 SOC. Q. 509 (1983) (discussing opportunity-based theories of criminality).

27. Departments of Commerce, Justice, and State, the Judiciary, and Related Agencies Appropriations for Fiscal Year 1996: Hearings on H. 2076 Before a Subcomm. of the Senate Comm. on Appropriations, 104th Cong. 328 (1995) (statement of Doris Meissner, Commissioner, Immigration and Naturalization Service) (reporting that the INS is focusing worksite enforcement upon repeat violators); Departments of Labor, Health and Human Services, and Education, and Related Agencies Appropriations for Fiscal Year 1996: Hearing Before a Subcomm. of the Senate Comm. on Appropriations, 104th Cong. 11 (1995) (statement of Robert B. Reich, Secretary of Labor) ("Our strategy will focus attention and target enforcement resources on repeat violators ....").

In the environmental enforcement context, both federal and state agencies focus primarily on repeat offenders. E.g., U.S. ENVTL. PROT. AGENCY, ENFORCEMENT FOUR-YEAR STRATEGIC PLAN: ENHANCED ENVIRONMENTAL ENFORCEMENT FOR THE 1990's, at 11 (1991) (describing a targeted enforcement approach based on "patterns of noncompliance... by particular corporations"); Melissa Jean Horne, Bad Actor Statutes: An Environmental Trojan Horse?, 48 VAND. L. REV. 771, 799 (1995) (reporting on the special allocation of state enforcement resources to investigate known "bad actors"); Officials Outline Enforcement Policies on Criminal Law Concerning the Environment, 58-9 Crim. L. Rep. (BNA) 1198-99 (Nov. 29, 1995) (reporting that FBI agents are directed to focus upon repeat offenders); James Strook \& William W. Carter, California's Integrated Enforcement Programs: State, Federal, and Local Coordination, 


\section{The Significance of Escalating Probabilities of Detection for Optimal Penalty Levels}

\section{A logical next inquiry is whether there are other factors weighing in}

C921 ALI-ABA 1023 (1994) (reporting that the California environmental agency is targeting repeat offenders in criminal and civil enforcement actions).

Several sources provide accounts of the targeting of repeat violators in a range of other regulatory contexts. See, e.g., Safety of Food Imports: Hearing Before the Permanent Subcomm. on Investigations of the Senate Comm. on Gov't Affairs, 105th Cong. 152 (1998) (statement of Raymond W. Kelley, Commissioner, U.S. Customs Service) (reporting that "repeat violators have been and will continue to be criminally prosecuted. Various criminal statutes related to smuggling, false statements, and conspiracy are available for use against serious or repetitive violators"); Nursing Home Neglect: Hearing Before the Senate Special Comm. on Aging, 105th Cong. 220 (1998) (statement of Michael Hash, Deputy Administrator, Health Care Financing Commission) (explaining that federal regulators direct state surveyors to "conduct inspections more often for repeat offenders with serious violations"); Fraud in the Micro-Capital Markets, supra note 4, at 133-34 (statement of Arthur Levitt, Chairman, U.S. Securities and Exchange Commission) (explaining that the Commission's limited resources are targeted at complaints against "rogue brokers"); OSHA: New Mission for a New Workplace: Hearing Before the Subcomm. on Human Res. and Intergovernmental Relations of the House Comm. on Gov't Reform and Oversight, 104th Cong. 52 (1995) (statement of Joseph A. Dear, Assistant Secretary of Labor for Occupational Safety and Health) (explaining that OSHA targets repeat violators to assure that "inspectors go to the most dangerous workplaces"); DIV. OF MKT. REGULATION, U.S. SECS. \& EXCH. COMM'N, THE LARGe FIRM PROJECT: A REVIEW OF HIRING, RETENTION AND SUPERVISORY PRACTICES 9 (1994) (describing an enforcement focus upon brokers who had been the subject of previous state or federal enforcement actions); U.S. SECS. \& EXCH. COMM'N, 1998 ANNUAL REPORT 53 (describing an enforcement approach that targets the greatest compliance risk); U.S. SECS. \& EXCH. COMM'N, 1997 ANNUAL REPORT 66 ("The examination staff continued to target for inspection those [investment] advisers posing a higher risk to clients"); Getting Tampa Up to Code, ST. PETERSBURG TIMES, Apr. 13, 1998, at 8 (reporting how city officials are targeting repeat offenders of public health and safety regulations); IRS Manual Instructs on Targets and Procedures for Repeat Trust Fund Violators, CCH Tax Day: Federal (July 13, 1994) (explaining that IRS guidelines "instruct officials to take into consideration the outcome of previous collection activity and attempts in determining what action to take. Forceful actions are recommended ... for cases in which prior IRS actions against the taxpayer did not result in compliance").

There has been much discussion of the targeting of offenders in the context of nonregulatory offenses. See, e.g., Departments of Commerce, Justice, and State, the Judiciary, and Related Agencies Appropriations for 1999: Hearings Before a Subcomm. of the House Appropriations Comm., 105th Cong. 409 (1998) (statement of John A. Calhoun, Executive Director, National Crime Prevention Council) (explaining that Boston's criminal enforcement strategy targets repeat offenders); Keeping Neighborhoods Safe, DETROIT NEwS, May 20, 1998, at A14 (discussing New York City's strategy of targeting repeat offenders); Mark Larabee, Identity Thieves Now Risk Felony Charges, OREGONIAN, Oct. 23, 1999, at C1 (documenting penalty escalation for credit card fraud); Michele M. Melendez, Fighting Crime Top Priority, Cleveland PLAIN DEALER, Aug. 3, 1999, at 1F (describing a city police program targeting repeat offenders); David Shepardson, Drunken Drivers Targeted: Repeat Offenders Will Find It Tougher To Get Back on the Road, DETROIT NEwS, Sept. 21, 1999, at C1 (reporting new laws geared toward stiffer punishments for repeat offenders); Ellen J. Silberman \& Andrew Miga, President Unveils AntiGun Initiative, BOSTON HERALD, Jan. 19, 2000, at 5 (describing Boston's successful police strategy of targeting repeat offenders); Richard Sine, Police Nab 36 in Drug Sweep, NEw ORLEANS TIMES-PICAYUNE, Oct. 19,1999, at B1 (describing a sweep aimed at repeat drug offenders); James Walsh, Catch \& Release Justice: 8,700 Offenders Evade Justice, Cost Millions, MINNEAPOLIS STAR TRIB., July 18, 1999, at $1 \mathrm{~A}$ ("[V]arious parts of the justice system are trying new ways to track and target repeat offenders."); Jon Yates, Police Target Repeat Offenders, TENNESSEAN, July 28, 1998, at 1B ("Police have begun compiling a list of the city's most violent offenders .... [T] he goal is to soon begin seeking longer terms for repeat offenders ...."). 
favor of escalation that offset or more than offset the effects of escalating probabilities of detection. The strongest possible factors, as suggested in the literature, are (1) the societal interest in conserving enforcement resources by imposing penalties only to the extent needed to deter any given individual or entity (or subpopulations of individuals or entities), and (2) the societal interest in avoiding mistaken punishments of individuals and entities. ${ }^{28}$ At least in the context of regulatory offenses, where the optimal level of deterrence is often less than maximal, neither of these factors obviously outweighs the argument for declining penalties on the grounds that repeat offenders face higher probabilities of detection.

\section{Conserving Enforcement Costs}

The enforcement regime faces a tradeoff between the goal of deterrence and the costs associated with maintaining severe sanctions, such as the heavy costs associated with successfully collecting large fines or maintaining prisons. Professors Polinsky and Rubinfeld have suggested that escalating penalties based on offense history may represent an optimal solution to the tradeoff dilemma: By reserving severe sanctions for those whose past unlawful conduct demonstrates that moderate sanctions will not deter them, the enforcement regime avoids the costs associated with maintaining generally applicable severe sanctions while achieving a high level of deterrence. ${ }^{29}$ The argument, in effect, is that it is efficient for the government to price-discriminate in setting penalties, charging the most severe or expensive penalties to violators who have shown that they would gain most from violations. ${ }^{30}$

28. One might also attempt to justify offense history as a mechanism to sort those offenders for whom incapacitation is socially beneficial in itself (apart from its deterrence effects) from those for whom it is not. That is, a history of repeated offenses may demonstrate that an offender has such an overwhelming propensity to recommit offenses-and such an obliviousness to incentives to comply with law-that the optimal option for society is simply to lock him or her up. Polinsky \& Shavell, supra note 1 , at 316 . This incapacitation rationale for penalty escalation may help explain the escalation from moderate prison sentences for a first or second offense to extraordinarily severe, draconian sentences for a next offense, as in the three-strikes-and-you'reout model. This incapacitation rationale, however, cannot readily explain penalty escalation in other contexts, most notably escalation in nonincapacitation penalties.

29. See Polinsky \& Rubinfeld, supra note 8.

30. Another way to characterize Polinsky and Rubinfeld's argument is as a sorting argument: Prior detected offenses help the government sort those individuals and entities who gain a great deal from lawbreaking from those who do not. Prior detected offenses also may help sort between those who consistently underestimate probabilities of detection due to cognitive biases (such as overconfidence) and those who make more accurate assessments. See infra Part III.

One could imagine a sorting argument based on offense history that would favor declining, rather than escalating, penalties based on offense history. A record of many prior detected offenses may be evidence not only of a strong propensity to violate the law, but also a lack of talent as a law violator. More talented violators may have thinner records or no records simply because they are better at evading detection. A long record of offenses thus may suggest a high probability of detection for one's next offense, whereas no record or a slim record may suggest a 
Polinsky and Rubinfeld's analysis is problematic in the context of offenses for which the optimal deterrence-level is not maximal deterrence. As discussed above, in the optimal-deterrence framework, optimal penalties are unrelated to the violator's gain from a violation; only the harm from a violation matters. The escalation of penalties based on offense history, as Polinsky and Rubinfeld cogently explain, reduces the likelihood that those who derive the most gains from violations will continue to commit violations. But a basic normative point of the theory of optimal deterrence is that where the violator's gains are sufficiently great-that is, great enough to outweigh the costs from the violation - the penalty regime should not deter the violation. Polinsky and Rubinfeld respond to this problem in their analysis by employing the assumption that the gains motivating violators are "other than ... socially acceptable gain" - that is, the gains are "illicit" and thus need not be considered in any calculus as to whether a violation of law is, on net, socially beneficial or costly. ${ }^{31}$ But conventional economic theory does not provide any basis for distinguishing between gains that are illicit and those that are not. Indeed, one could argue that all private gains or benefits from violating the law are by definition socially illicit, but from an aggregate welfare maximization perspective, they are equivalent to gains derived from lawful activity. Polinsky and Rubinfeld's analysis is more persuasive if it is limited to categories of offenses that invariably entail greater social harm than benefit to the violator, such as violent crimes and nonviolent, but coercive, transfers like theft. For such offenses, optimal deterrence is maximal deterrence, and Polinsky and Rubinfeld's analysis usefully explains how penalty escalation can promote maximal deterrence while limiting the societal costs associated with maintaining generally applicable high sanctions.

Even with respect to offenses where maximal deterrence is desirable, however, the fact that probabilities of detection escalate may mean that escalation in formal penalties is not necessary in order to create a set of successively stronger deterrents. Assume, for example, that the harm from some offense is immense, but in order to conserve on enforcement costs, the optimal policy is to establish an expected penalty of $\$ 1$ million for a

comparatively low probability of detection for one's next offense. To the extent this is true, the optimal-deterrence model would suggest that the optimal sanction for an offender with a record should be lower than that for an offender without a record. The much stronger argument for declining penalties based on offense history, however, relates to the government's acquisition of information by means of the process of detecting and punishing offenses. See supra Sections II.A-C.

Burnovski and Safra have argued that declining penalties for repeat offenses might be optimal, but their highly technical model is limited to an extremely rare factual setting--that is, a setting where the offender chooses in advance to commit multiple offenses and the offender cannot modify this decision after the detection of one or more of the contemplated multiple offenses. See Burnovski \& Safra, supra note 1, at 343.

31. Polinsky \& Rubinfeld, supra note 8, at 292. 
first violation, $\$ 10$ million for a second violation, and $\$ 100$ million for a third violation. Also assume, contrary to Polinsky and Rubinfeld, that the probability of detection escalates, so that pdet for a first violation is 0.001 , for a second violation 0.01 , and for a third violation 0.1 . Under these factual assumptions, even assuming the state does want to achieve a tenfold escalation in expected penalties for each repetition of the violation, nonescalating, constant formal penalties (a fine of $\$ 1$ million for first, second, and third violations) would achieve that objective. ${ }^{32}$

\section{Avoiding Mistakes}

The factual mistakes theory, as developed by Rubinstein and $\mathrm{Chu}, \mathrm{Hu}$, and Huang, ${ }^{33}$ starts with the assumption that there is often a significant risk that the government or the courts will wrongfully convict a person. Consider the example offered by Rubinstein: “A person is caught leaving a supermarket with unpaid for merchandise in his possession. [One] doubt[] [is that]... possibly someone else might have placed the merchandise where it was found without the person's knowledge." ${ }^{34}$ If the law punishes the person who is only doubtfully culpable, a "miscarriage of justice" may result, and, from a deterrence perspective, there is the potential for significant overdeterrence costs (for example, shoppers shunning stores and towns thought to have extreme shoplifting policies, shoppers wasting time

32. Polinsky, writing with Shavell, subsequently has argued that escalating penalties based on offense history may result in optimal levels of deterrence even assuming that a record of prior convictions provides the government with no useful information for the purpose of sorting prospective offenders. Polinsky and Shavell develop their argument in the context of a model of a two-period game, in which a player can choose to commit an offense for the first time in either period one or period two. According to the model, maintaining higher penalties for a second offense (by definition here, a period two offense) strengthens the deterrence regime vis-à-vis period one offenses, because

[w]hen an individual contemplates committing an offense in the first period, he will realize that if he is caught, not only will he bear an immediate sanction, but also-because he will have a record-any sanction that he bears in the second period will be higher than it would be otherwise.

Polinsky \& Shavell, supra note 1, at 305 . But as Polinsky and Shavell themselves emphasize, penalty escalation based on offense history involves, in effect, reduced or lower penalties for those who commit their first offense in the second period, and in that way penalty escalation weakens deterrence of first offenses in the second period. Thus, from a deterrence perspective, penalty escalation entails a tradeoff between increased deterrence in the first period and decreased deterrence in the second period. And as Polinsky and Shavell candidly admit, there is no empirical or factual basis for assuming that the tradeoff results in greater net deterrence in any case, let alone most cases: It simply could be so sometimes. Id. at 311-13.

33. See Chu et al., supra note 1; Ariel Rubinstein, On an Anomaly of the Deterrent Effect of Punishment, 6 ECON. LeTTERS 89 (1980); Ariel Rubinstein, An Optimal Conviction Policy for Offenses That May Have Been Committed by Accident (Hebrew Univ. of Jerusalem, Research Report No. 114, 1979) (unpublished manuscript, on file with author) [hereinafter Rubinstein, Optimal Conviction Policy].

34. Rubinstein, Optimal Conviction Policy, supra note 33, at 1. 
scrutinizing their shopping carts before they leave stores). In such cases, because of factual doubts, the optimal sanction may be zero or a small fine.

Where the person with the unpaid-for goods has a record of previous shoplifting offenses, however, the calculus may be quite different. It may be plausible to believe that, by random chance, a shopper can leave a store once with goods placed in his cart by someone else. But the probability of that happening more than once is very slim, and so the likelihood that a second arrest and conviction for shoplifting reflects a factual mistake is also very slim, perhaps nonexistent. Similarly, while it may be plausible that a given person will be wrongly identified once by a robbery victim, multiple wrongful identifications seem quite unlikely. The appropriate penalty for a second offense thus should be higher than the penalty for a first offense, as it need not reflect a discount for the possibility that the conviction is factually mistaken.

As an explanation for the general practice of escalating penalties based on offense history, the factual mistakes theory has substantial limitations. First, it is not obvious that a significant possibility of factual error exists for all or even perhaps most first offenses. Some kinds of offenses have relatively straightforward, simple legal requirements, and thus give rise to very low risks of mistaken conviction. ${ }^{35}$ Moreover, if penalty escalation reflects only the risk of factual error, one would expect to see a significant increase in penalty severity between first and second offenses, but little or no increase thereafter: The likelihood that a shopper somehow ends up with someone else's shopping bags when he leaves the store dramatically drops after one shoplifting arrest and probably is negligible thereafter no matter how many times he is arrested and claims he is the victim of a factual mistake. ${ }^{36}$

35. In particular, many civil regulatory offenses and even many criminal regulatory offenses are strict or quasi-strict liability offenses, and thus do not implicate factually difficult questions about the reasonableness of the defendants' conduct or their state of mind. See generally Stuart $P$. Green, Why It's a Crime To Tear the Tag off a Mattress: Overcriminalization and the Moral Content of Regulatory Offenses, 46 EMORY L.J. 1533 (1997) (reviewing reduced or eliminated intent requirements for regulatory crimes); Richard J. Lazarus, Meeting the Demands of Integration in the Evolution of Environmental Law: Reforming Environmental Criminal Law, 83 GEO. L.J. 2407 (1995) (exploring and criticizing the reduced intent requirements for environmentai crimes).

36. A wide variety of statutes and sentencing guidelines specifically provide for escalation in penalties after the second offense. Lexis and Westlaw searches of state statute databases revealed scores of provisions of this kind. E.g., IOWA CODE § 321J.2(2)(b), (c) (1999) (providing that the third drunk driving offense constitutes a felony with a one-year-maximum prison sentence, while a second offense constitutes only a misdemeanor); TEX. PARKS \& WILD. CODE ANN. $\$ \S 12.404$, $12.405,77.020$ (c) (Vernon 1991 \& Supp. 2001) (providing a maximum fine of $\$ 4000$ and maximum imprisonment of one year for a third violation, in contrast to a maximum fine of $\$ 2000$ and 180 days' imprisonment for a second violation). The federal sentencing guidelines dictate upward adjustments for each prior sentence of imprisonment so that the upward adjustment for two prior sentences is double that for one prior sentence. U.S. SENTENCING GUIDELINES MANUAL $\S 4$ Al.1(a), (b), (c) (1998). 


\section{HeURISTIC BIASES AND PENALTY ESCALATION BASED ON OFFENSE HISTORY}

So far, this Article has not solved the puzzle of escalating penalties based on offense history; indeed, the analysis so far has revealed that the tension between conventional economic theory and penalty escalation is even greater than previously realized. One possible place to look for aid in solving this deepening puzzle is the burgeoning literature regarding heuristic biases. In recent years, cognitive psychologists and experimental economists have conducted a number of laboratory experiments that suggest that people generally do not behave in accord with the rationalactor model that is the starting point for the optimal-deterrence construct and other microeconomic models. Instead, people have certain biases that color the way they process information, with the result that they often opt for (what might be termed) irrational behaviors. ${ }^{37}$ To the extent that this growing body of empirical study captures fundamental truths about human cognition, it may provide a justification for some practices and policies that seem untenable under a traditional rational-actor analysis. Thus the question I explore here: If one attributes to potential offenders the cognitive biases suggested in the existing empirical literature, does the practice of escalating penalties based on offense history seem more consistent with the goal of achieving optimal deterrence? The answer, it seems, is no: Consideration of at least two of these biases-the salience bias and the optimism biassuggests that penalties should not escalate based on offense history and, perhaps, penalties should decline based on offense history, at least for some categories of offenses.

\section{A. Salience/Availability and Optimism Biases}

The cognitive psychology literature regarding salience suggests that people do not process and weigh all information according to rational criteria. Instead, three distortions exist that commonly-and here I will follow the general practice-are conflated under the label of the salience or availability heuristic. The first distortion concerns the different weight people place on first-hand, direct experience as opposed to information about the experience of others. As reflections on one's own decisionmaking process (or at least mine) would confirm, people tend to find much more available-easier to bring to mind-their own, directly lived experiences and hence tend to weigh them heavily (from a rational perspective, too 
heavily) in decisionmaking. ${ }^{38}$ Second, as between recent and distant personal experience, recent personal experience is more psychologically available to people and hence may. be weighed more heavily than distant experience. ${ }^{39}$ Third, as regards either personal experience or secondhand information, vivid, dramatic, and "showy" events (sudden death from explosions, hurricanes) are more psychologically available than more subtle, less easily visualized, less dramatic information events (long-term risks from poor diet, global warming). ${ }^{40}$ And, for that reason, at least on some accounts, people respond to (and get politicians to respond to) dramatic threats to well-being aggressively, while essentially ignoring longterm, sometimes much more serious but less vivid threats. ${ }^{41}$ To summarize then: In decisionmaking, people will overweigh the importance of their most recent, most vivid, first-hand experiences.

A related-but distinct-bias is the optimism bias. According to some of the experimental literature, people tend to be very optimistic about their likelihood of escaping bad events or bad circumstances (for example, disease or accident): In the vernacular, and even when faced with good information to the contrary, people tend to think, "It can't happen to me." 42 To some extent the optimism bias may simply be a manifestation of the salience/availability bias. That is, people may overestimate their chance of avoiding an accident while speeding simply because they never have had a firsthand experience of getting into an accident while speeding. The experimental literature suggests, however, that excessive optimism is not simply the product of salience. It also appears to be a product of a deep human need to believe strongly in one's own capacities and abilities. Thus, evidence of optimism is strongest in studies in which subjects are asked to evaluate risks where their own skillfulness would have a major impact on

38. See Jon D. Hanson \& Douglas A. Kysar, Taking Behavioralism Seriously: The Problem of Market Manipulation, 74 N.Y.U. L. REV. 630, 654-72 (1999) (reviewing salience, optimism, and other biases); Amos Tversky \& Daniel Kahneman, Judgment Under Uncertainty: Heuristics and Biases, in JUDGMENT UNDER UNCERTAINTY 3 (Daniel Kahneman et al. eds., 1982).

39. See Norbert Schwarz et al., Ease of Retrieval as Information: Another Look at the Availability Heuristic, 61 J. PERSONALITY \& SOC. PSYCHOL. 195, 195 (1991); Tversky \& Kahneman, supra note 38, at 11.

40. See Paul Slovic, Perception of Risk, 236 SCIENCE 280, 283 (1987) (discussing “dread risk").

41. See StePhen BREYer, BREAKING the Vicious CirCLe 6-7, 33-39 (1993) (criticizing American environmental law as reflecting public misperceptions of risk).

42. See Lynn A. Baker \& Robert E. Emery, When Every Relationship Is Above Average: Perceptions and Expectations of Divorce at the Time of Marriage, 17 LAW \& HUM. BEHAV. 439 (1993) (arguing that newlywed couples have unrealistic assessments of the likelihood that their marriages will not end in divorce); Ola Svenson, Are We All Less Risky and More Skillful than Our Fellow Drivers?, 47 ACTA PSYCHOLOGICA 143 (1981) (reporting that a majority of drivers rate themselves as above-average drivers); Neil D. Weinstein, Unrealistic Optimism About Susceptibility to Health Problems: Conclusions from a Community-Wide Sample, $10 \mathrm{~J}$. BEHAV. MED. 481, 489 (1987) (concluding, based on survey data, that an optimistic bias about susceptibility to harm is not limited to any age, sex, or occupational group). 
the outcome-say, the case of driving at high speed. Evidence of optimism is weakest when subjects are asked to evaluate risks that are environmental and which therefore are clearly beyond the subjects' control..$^{43}$ In sum, individuals will tend to underweigh the risk of some bad outcome unless they have personally experienced such an outcome before, and this underweighing will be particularly significant where the individuals' own behavior (for example, skillful driving at high speeds) would affect whether they fall victim to the bad outcome.

To the extent that they actually exist, the salience and optimism biases are presumably most robust where secondhand, nonpersonal information is simply unavailable to the decisionmaker or, if available, would be very expensive to collect and verify. In such cases of imperfect information, the notion that decisionmakers will rely on what they know-their own personal experience-seems intuitively correct even if one posits that the decisionmakers know or should know that their personal experience may not be typical and hence predictive of future events. ${ }^{44}$ By contrast, where the decisionmaker is squarely presented with verified secondhand information contrary to his or her personal experience, one nonetheless might expect the decisionmaker to overweigh his or her personal experience, but not to rest his or her decision solely on an extrapolation from that personal experience. Thus, in assessing the relevance of the salience/optimism biases to prospective offenders' assessments of probabilities of detection, an important question is what kind of information prospective offenders have in making their assessments. If, for example, such prospective offenders are largely limited to information based on their own personal experience, then one might predict that pdet assessment will be strongly affected by salience/optimism biases.

43. See Neil D. Weinstein, Optimistic Biases About Personal Risks, 246 SCIENCE 1232 (1989) (discussing the strong correlation between optimism and the extent to which a given hazard or risk is perceived by the test subject to be "controllable"); Neil D. Weinstein \& William M. Klein, Resistance of Personal Risk Perceptions to Debasing Interventions, HEALTH PSYCHOL. $132,132-33$ (1995) (presenting data suggesting that optimistic biases persist even in the face of "debasing interventions" and concluding that optimism does not reflect simply a lack of experience or information "but also... the motivation to avoid anxiety ... and to maintain self-esteem ... which [makes] it more resistant to change").

44. Indeed, some critics of the salience/optimism literature argue that the experimental tests conducted to date do not demonstrate irrational, biased decisionmaking at all, but rather entirely rational decisionmaking given the informational constraints facing decisionmakers. One other set of objections to the cognitive psychology literature concerns the basic methodology employed to demonstrate the effect of salience and optimism: that is, relatively small-group simulations or surveys, often with students as the subjects. Small groups of students may not reflect the diversity of people and groups of people who make decisions in the world; students in any event may not try to act or respond in a simulation or survey context as they would in real life; and even where the subjects do try to respond as they would in real life, the simulations or surveys may provide too simplified a context for them to employ the kind of reasoning and emotional processes that they would employ outside the laboratory. See generally Jeffrey J. Rachlinski, The "New" Law and Psychology: A Reply to Critics, Skeptics, and Cautious Supporters, 85 CORNELL L. REV. 739, 741-60 (2000). 
And, in fact, prospective offenders often may find it costly to acquire and verify secondhand information regarding the probabilities of detection in different contexts and, for that reason alone, may extrapolate solely from their own personal experiences. In order to make a meaningful guess as to pdet based on other people's experiences, one would need to know how often other people broke the law and got away with it; data on the number of penalties and punishments, standing alone, would not be terribly helpful. There are at least two possible sources of information regarding successful (that is, unpunished) lawbreaking: the government, and noncomplying entities and individuals themselves. But neither of these sources is apt to share this sort of information.

For its part, the government simply may not know how many undetected violations of law occur. Some sorts of crimes-notably crimes that result in concrete harm to specific, identifiable individuals, such as robbery-are often reported to the police, and the police do maintain statistical databases. But underreporting is common in some contexts. Moreover, there are many civil and criminal offenses that do not have identifiable victims, such as tax evasion, noncompliance with Clean Air Act permits, and speeding on highways. For such offenses, the government can detect noncompliance only by affirmatively engaging in inspections, and for a variety of reasons (but most notably resource constraints), it typically inspects on a very limited, very sporadic basis.

Moreover, the government may have good reasons not to share the information it does have regarding the extent and nature of successful noncompliance. For one thing, news of widespread successful noncompliance embarrasses government officials and may be politically damaging. Moreover, government officials may well believe that disseminating information regarding rates of successful noncompliance in various contexts will have socially counterproductive results: The disseminated information will inform would-be lawbreakers of the most promising opportunities for low-risk lawbreaking and thus encourage more lawbreaking in the aggregate. At any rate, one thing seems clear: While it is relatively easy to pick up criminal codes and guidelines and look up the minimum and maximum sentences for a given crime, there is no comparable place to look up the ratios of successful to unsuccessful violations of different offenses.

The other source of information regarding detection rates, of course, is offenders themselves. If, for example, a thousand routine parking code violators could pool their information regarding where and when the police focus their enforcement attention, they probably could arrive at a much better model of the probability of future detection than if they each operated solely on the basis of their own personal experience. Cooperation among fellow offenders, however, is costly. As with any collective enterprise, there 
would be transaction costs: Consider the costs of identifying and arranging information exchange among a thousand parking code violators. Moreover, exchanging information about one's past illegal conduct itself is risky: Your fellow offender may be a police officer or he may turn you in to the police or seek to blackmail you. Finally, to the extent that offenders compete with each other for "business" (for example, competing drug dealers in a town), they have a good reason not to assist each other by providing information about their detection experiences.

\section{B. A Simple Two Time Period Model}

A simple thought experiment may help show how the salience and optimism biases, assuming they do exist in the world and do affect prospective lawbreakers, might affect estimates of probabilities of detection and hence their estimates of expected penalties. Imagine that three players-imaginatively named $A, B$, and $C$-are participating in a twoperiod game, in which, at the commencement of each period, each player must choose whether to comply with or violate a certain legal prohibition. The same sanction would apply to all three players in the event of detection.

Imagine that, in period one, $A$ decides to forgo committing the offense, but $B$ and $C$ commit the offense (perhaps because their expected gain from doing so exceeds $A^{\prime}$ 's). Reflecting the fact that detection is imperfect, only $B$ is caught and punished. At this point, $A, B$, and $C$ represent three subpopulations of prospective period two offenders: $A$ represents the population of people who have never previously committed an offense but might do so in the future; $B$ represents the population of people who have violated the law and gotten caught; and $C$ represents the population who have violated the law without getting caught.

How would $A, B$, or $C$ perceive the probability of detection for a period two violation? Begin the analysis by assuming both that the salience/optimism biases do not exist and that $A, B$, and $C$ have perfect information-that is, each player not only knows about his or her compliance/detection history, but he or she also knows about the other players' histories. Under these assumptions, all three players would know that two violations had occurred during period one and that one had been detected, so their best historically-based estimate of pdet for a period two violation probably would be 0.5 . Depending on their attitudes toward risk, and their expected gain, they might make the same or different choices as they did for period one. In any event, there is no reason to believe that they would have different estimates of pdet or the expected penalty for a period two violation. 
Now relax the assumption of perfect rationality, and assume that $A, B$, and $C$ are subject to salience/optimism biases. ${ }^{45}$ Continue to assume, however, that each player has perfect information. Under these assumptions, $A, B$, and $C$ would each know that, in their pooled experience, the best historically-based estimate of $p d e t$ for a period two violation is 0.5 . But because of the salience bias, $B$ presumably would make some upward adjustment in his estimate of pdet to reflect the salience of his recent detection. For her part, $C$ would make some downward adjustment in pdet to reflect her recent success in avoiding detection. To the extent that the optimism bias stands alone from the salience bias, both $A$ and $C$ presumably would make some downward adjustment to reflect their continuing optimistic assessment of their ability to avoid bad outcomes in life. $B$ 's natural optimism may well have been checked by his recent detection. So, overall, one might expect $C$ to have the lowest estimate of $p d e t$ for a period two violation, $A$ to have a somewhat higher estimate, and $B$ to have the highest estimate. Consequently, if the goal of the law is to present each player with the same expected penalty for a period two violation (given that the harm from a violation would be the same whether the offender is $A, B$, or $C$ ), then the formal sanction in period two for a violator with a record $(B)$ should be less than the formal sanction for a player without a record ( $A$ or C).

Would this counterintuitive result obtain if one assumes, more realistically, that $A, B$, and $C$ cannot effectively pool information about their compliance/detection experience? In fact, where $A, B$, and $C$ are limited to their own personal experience, and each operates under a salience bias, the counterintuitive result is even more robust. Because $B$ 's only experience is a single detected violation, his historically based estimate of pdet for period two would approach one (100\%). C's experience of a single undetected violation would lead her to estimate pdet for period two as something approaching zero. Of course, $A$ does not have any relevant experience since he has not violated the law. But if people truly are optimistic about risks of bad outcomes in the absence of any direct experience with those risks, then one might expect $A$ 's estimate of $p d e t$ for a period two violation to be closer to $C$ 's than $B$ 's. Thus, once again, $A$ and $C$ 's estimate of $p d e t$ will be lower than $B$ 's. And, if the expected penalty for each player is the same, the formal sanction for the player with a record $(B)$ should be less than the formal sanction for the players without a record $(A$ and $C$ ).

45. Cf. Braithwaite, supra note 24 , at $1747-48$ (suggesting that because of the salience of a recent detection, "[e]very preventive law practitioner knows the best time to put in place a new corporate compliance system is after a company has got into trouble with a regulatory agency"). 


\section{Moving Beyond a Two-Period Model}

Would the results above obtain in the more realistic situation in which the relevant time frame is not just two periods but four periods or, for that matter, a hundred? The short answer is that the extension of the relevant frame period makes it somewhat harder to predict whether different subpopulations of prospective offenders will have different pdet estimates and hence should be subject to different sanctions. But this much, at least, is clear: There is no salience/optimism basis for the general practice of escalating penalties based on offense history and, in some subset of the possible cases, salience/optimism considerations actually support lower penalties for offenders with a record than for those without.

As a starting point, once again imagine that players $A, B$, and $C$ represent three distinct subpopulations of prospective offenders: prospective offenders who have never violated the law $(A s)$, prospective offenders who have violated the law and been caught $(B \mathrm{~s})$, and prospective offenders who have violated the law but not been caught (Cs). Unlike in the two-period model, all three players have had multiple previous opportunities to comply with or violate the law. In that case, what can be said generally about how $A, B$, and $C$ may view the probability of detection of a violation in the next time period?

$B$ 's assessments of pdet will likely be colored by his experience having violated the law and been caught, an experience that neither $A$ nor $C$ has had. On the other hand, it is probable that $B$ has had more experiences violating the law successfully-that is, without being caught-than either $A$ (who, as posited, has no such experiences) or $C$ (who is posited to have had at least one such experience). Why is it reasonable to assume that violators with a record have, on average, successfully violated the law more often than violators without a record? Consider that if the actual probability of detection for a certain kind of violation is, say, 0.05 , those who commit fourteen or more violations are more likely than not to have at least one detected violation. Those who commit fewer than fourteen violations are more likely than not to have zero detected violations. ${ }^{46}$ In other words, the presence or absence of a detected violation in a subpopulation is a good indicator of the average number of violations committed by members of that subpopulation, and the average number of violations committed by members of the subpopulation is a good indicator of the average number of

46. A 95\% chance that one offense will go undetected, raised to the fourteenth power, results in a $48.77 \%$ chance that all fourteen offenses will go undetected; for thirteen offenses, the figure is $51.33 \%$. 
undetected violations committed by members of the subpopulation. ${ }^{47}$ If this analysis is correct, $B$ probably will have some personal experience-the experience of a comparatively larger number of successful past violationsthat will tend to make him estimate a lower pdet for a next-period violation than either $A$ or $C$. How past violators with a record such as $B$ balance these two distinct personal experiences-the experience of detection and the experience of a comparatively large number of undetected violations - may depend on which experience is most recent and hence presumably most salient.

Consider, for example, a situation where the players, $A, B$, and $C$, have had three previous opportunities to comply with or violate the law, and the question now is what they will do in period four. Assume, consistent with the preceding discussion, that $B$ has more undetected past violations (say, two) than $C$ (say, one). If (for simplicity) one assumes that $C$ 's single undetected violation occurred during period three of the game, then there are three possible variants on the compliance/detection histories of $A, B$, and $C$, which are represented below in Figure 1:

\section{FIGURE 1}

\section{VARIANT A}

\begin{tabular}{|c|c|c|c|}
\multicolumn{1}{c}{} & \multicolumn{1}{c}{ A } & B & C \\
\hline $\begin{array}{c}\text { Period } \\
1\end{array}$ & Compliance & Undetected & Compliance \\
\hline \hline Period & Compliance & Undetected & Compliance \\
2 & & Violation & \\
\hline $\begin{array}{c}\text { Period } \\
3\end{array}$ & Compliance & Detected & Undetected \\
Violation \\
\hline
\end{tabular}

\section{VARIANT B}

\begin{tabular}{|c|c|c|c||}
\multicolumn{2}{c}{ A } & B & C \\
\hline $\begin{array}{c}\text { Period } \\
1\end{array}$ & Compliance & Undetected & Compliance \\
\hline \hline $\begin{array}{c}\text { Period } \\
2\end{array}$ & Compliance & Violation & \\
\hline $\begin{array}{c}\text { Period } \\
3\end{array}$ & Compliance & Violation & Compliance \\
\hline
\end{tabular}

47. Note that this analysis assumes that all of the different subpopulations have equal skill in evading detection. But see supra note 30 (exploring the proposition that repeat offenders have below average skill in evading detection). 
VARIANT C

\begin{tabular}{|c|c|c|c|}
\multicolumn{1}{c}{} & A & B & C \\
\hline $\begin{array}{c}\text { Period } \\
1\end{array}$ & Compliance & Detected & Compliance \\
& & Violation & \\
\hline $\begin{array}{c}\text { Period } \\
2\end{array}$ & Compliance & Undetected & Compliance \\
\hline $\begin{array}{c}\text { Period } \\
3\end{array}$ & Compliance & Violation & \\
\hline
\end{tabular}

If $A, B$, and $C$ suffer from salience/optimism biases but each have perfect information (information about one another and not just themselves), they would know that the total number of detections per violation has been one out of four. Their most rational, historically based estimate of pdet for a next-period violation thus might be 0.25 . But $C$ might be inclined to estimate pdet for the next period as lower than 0.25 because the only direct and thus salient experience she has had is a successful violation; nothing has occurred which would unsettle her natural optimism. The same is true of $A$; his optimism should be intact. By contrast, if $B$ were to rely solely on his own experience to estimate pdet, he might be inclined to an estimate of 0.33 , since he has violated the law three times but been caught only once. $B$ 's estimate of pdet might be lower, however, if the detected violation occurred a long time ago (in period one), so that his more recent and salient experiences would be successful violations. By the same token, if the detected violation occurred in period three, $B$ might estimate pdet as higher than 0.33 , even though the detected violation was preceded by two undetected violations. Thus, the question of whether $B$ will estimate pdet as higher or lower than $A$ or $C$ may turn on the temporal distribution of $B$ 's experiences: whether his detection experience follows his successful violation experiences (as in Figure 1, Variant A), or whether his detection experience precedes his successful violations experiences (as in Figure 1, Variant C).

The possibility that $B$ will estimate a higher pdet for a next-period violation than $A$ and $C$ becomes even more remote if one assumes that $A$, $B$, and $C$ each have access only to their own personal detection/compliance histories. In that case, $C$ 's historically based estimate of pdet presumably will approach zero, whereas $B$ 's historically based estimate of pdet will be 0.33. Even if $A, B$, and $C$ are in a Figure 1, Variant $C$ situation, and $B$ suffers from a robust salience bias, it seems unlikely that $B$ then would arrive at an estimate of pdet that is as low as $C$ 's. 


\section{Moving Beyond Simple Record/No Record Comparisons}

As indicated above, a regime of escalating penalties based on offense history does not simply entail higher penalties for those with a record of violation as compared to those without such a record, but also entails higher penalties for those with a relatively large number of past detected violations than for those with relatively few or only one past detected violation. Can salience/optimism biases explain this aspect of the escalating penalties regime? The answer, once again, appears to be no.

To consider this issue, now assume that $B$ represents a subpopulation with two detected violations and $C$ represents a subpopulation with only one detected violation. In that case, $B$ will have had more experiences of detection than $C$, which would (given operation of a salience bias) tend to lead $B$ to arrive at a higher estimate of pdet for a next-period violation than $C$. On the other hand, $B$ probably will have had more successful violations than $C$, which would tend to lead $B$ to arrive at a lower estimate of pdet than $C$. The pdet estimates of $B$ and $C$ will depend in part (again, given a salience bias) on the temporal distribution of both $B$ 's and $C$ 's successful and unsuccessful (detected) violations.

Consider, for example, a comparison of the situations depicted by Figures 2 and 3. In Figure 2, $B$ has more successful violations than $C$, but those violations were followed by two detected violations. $C$ has one detected violation, but that detected violation was followed by two successful violations. It thus seems likely, once again given the salience bias, that $B$ will have a higher estimate of $p d e t$ for the next period than $C$.

FIGURE 2

B

C

\begin{tabular}{|c|c|c|}
\hline $\begin{array}{c}\text { Period } \\
1\end{array}$ & Undetected & Compliance \\
\hline Period & Uiolation & Compliance \\
2 & Violation & \\
\hline \hline $\begin{array}{c}\text { Period } \\
3\end{array}$ & Undetected & Detected \\
\hline Period & Violation & Violation \\
4 & Violected & Undetected \\
\hline Period & Detected & Violation \\
5 & Violation & Undetected \\
\hline
\end{tabular}

In Figure 3, where the distribution of detected and successful offenses is reversed, one would expect the opposite to be true: $C$ will have a higher 
estimate of pdet than $B$ because $C$ 's most recent and hence salient experience is an unsuccessful violation whereas $B$ 's most recent and hence salient experiences are successful violations. In such a case, if the goal of the law is to present all parties with the same expected penalty, the law should set a lower sanction for offenders with one past-record offense (Cs) than for offenders with two past-record offenses $(B s)$.

\section{FigURE 3}

B

\begin{tabular}{|c|c|c|}
\hline $\begin{array}{c}\text { Period } \\
1\end{array}$ & Detected & Compliance \\
\hline Period & Violation & \\
\hline 2 & Detected & Compliance \\
\hline Period & Violation & Undetected \\
3 & Undetected & Violation \\
\hline \hline Period & Violation & Undetected \\
4 & Undetected & Violation \\
\hline \hline Period & Violation & Detected \\
5 & Undetected & Violation \\
\hline
\end{tabular}

This analysis also strongly suggests that past offenders who have a very recent past offense should face lower formal sanctions for a next-period offense than past offenders who have a very distant past offense. Note, however, that the law often works in exactly the opposite way. As a formal and informal matter, the law often treats offenders with a distant past offense only slightly more harshly than offenders with a clean record. ${ }^{48}$ By contrast, peculiarly severe punishments are reserved for offenders who have been caught committing one offense right after another. This pattern suggests, once again, that something other than deterrence concerns-or

48. For example, OSHA only regards a violation as a repeat violation subject to heightened penalties if the previous violation occurred within the past three years. Melli, Walker, Pease \& Ruhly, S.C., Serious, Repeat, Willful OSHA Violations Mean Bigger and Bigger Penalties, 7 WIS. EMP. L. LETTER, No. 11, Nov. 1998, at 6. There are various other examples of the discounting or nonconsideration of distant past offenses. See, e.g., Incentives for Self-Policing: Discovery, Disclosure, Correction and Prevention of Violations, 60 Fed. Reg. 66706, 66712 (Dec. 22, 1995) (providing lower penalties for entities that have discovered violations during an audit process if the same or a closely related violation has not occurred previously within the past three years); U.S. SENTENCING GUIDELINES MANUAL § 4al.1 (1998) (excluding prior sentences that are more than fifteen years old from the upward adjustment calculation for past criminal history); Peter G. Chronis, Drunk-Driving Deaths Fall, Summer's Sharp Decline a Result of Wider Enforcement, Officials Say, DENVER POST, Dec. 8, 1999, at Al (describing Colorado's drunken driving law that "stiffens penalties for people convicted of drunken driving more than once in five years"). 
more precisely optimal-deterrence concerns-are driving our sanctions practices.

\section{E. A (Very) Modest Step Toward Empirical Substantiation}

The previous analysis, of course, is based on hypothetical constructions of the psychology of hypothetical actors, and there are certainly limitations to that approach. Direct evidence of how prospective offenders in the world perceive probabilities of detection is difficult to obtain, for a whole host of reasons. Moreover, while there are simulation "laboratory" studies testing hypotheses regarding salience and optimism, none of these studies addresses the context of perceived probabilities of detection for future offenses. One might question, therefore, whether the findings in these laboratory studies can be extrapolated to the context of perceived probabilities of detection (even assuming that laboratory studies in general are a helpful mode of empirical study). And it may well be that any laboratory studies regarding law violations and compliance will fail to provide reliable results because of the subjects' desire not to reveal themselves as potential lawbreakers (even on confidential or nameless surveys) or because, for some subjects, lawbreaking of most sorts is outside their ordinary experience.

Despite these arguable problems with laboratory studies regarding assessments of probabilities of detection, such studies may be worth undertaking, as long as one is careful not to ascribe too much weight to their results. ${ }^{49}$ In this spirit, I undertook a simple survey test designed to discern whether potential lawbreakers would extrapolate from personal experience under conditions of imperfect information in a manner that is consistent with the salience/optimism account of decisionmaking. A group of eighty-one law students were given the following scenario: You recently became a contractor in a town that requires contractors to acquire an expensive permit for each home renovation job. The town randomly inspects a certain number of home renovation sites that are visible from the street to check whether the contractor on site has the required permit; violators detected during such inspections are fined; and since the town is undergoing a renovation boom, there are many hundreds of active renovation projects at any given time. The students were told that they have completed only one renovation project to date, and that they failed to get the required permit for the project. Half the students were told that the town authorities detected their violation of the permit requirement and imposed a

49. For an endorsement of empirical research into the influence of cognitive biases such as overconfidence on deterrence, see Russell B. Korobkin \& Thomas S. Ulen, Law and Behavioral Science: Removing the Rationality Assumption from Law and Economics, 88 CAL. L. REV. 1051, $1091-95$ (2000). 
fine. The other half were told that the town authorities had not detected their violation of the permit requirement. All of the students were then told that they were about to begin a new renovation project, and they were asked how likely it was that the authorities would detect their failure to obtain a permit for that project. The rating of likelihood of detection was on a 5point scale, with 5 signifying very likely, 4 somewhat likely, 3 unsure, 2 somewhat unlikely, and 1 very unlikely. The students were then asked to explain, in a paragraph or two, the reasoning behind their ratings of the likelihood of detection. ${ }^{50}$

My hypothesis in conducting the survey was that, if students did not suffer from a salience bias, the students who were told that they had one detected violation and those who were told they had one undetected violation would not differ very substantially in their assessments of the likelihood of future detection, because they would not place much weight on a single detection/nondetection experience that, for all they knew, might be very atypical. Conversely, if the students did suffer from a salience bias, the average assessment of the two groups of students would be significantly different. And, in fact, they were. On a scale of 1 to 5, among the students who had experienced one detected violation, the average assessment for detection of a future violation was 4.3 . The average for the group with one undetected violation was 2.0 .

The students' explanations of their results were interesting in two respects. First, as the numerical results would suggest, very few students expressed any recognition of or interest in the question whether it was reasonable to extrapolate from a single historical experience; most apparently did so without hesitation, a fact that suggests the robustness of the salience bias. Second, a relatively large number of the students (eight) in the group with one previous detected offense explained their assessment of the likelihood of detection of a future offense in terms that, essentially, track the analysis in Part III of this Article. That is, they explained that they believed that once they had been caught violating the permit requirement, the authorities would have them "on the list" of contractors to focus upon

50. The background information provided to all the students was the following:

You have just gone into the home renovation business as a contractor in the municipality of Pleasantville. The process of obtaining a permit is burdensome and entails delay. Consequently, for any given home renovating project, the contractor's profit will be approximately $\$ 10,000$ higher if the project is done without the required permit than if it is done with the required permit. Pleasantville's municipal code provides for a $\$ 20,000$ penalty for any contractor who undertakes a renovation without a permit. Pleasantville is undergoing a renovation boom, so there are several hundred renovation projects ongoing at any given time. Pleasantville enforces its permit requirement by randomly inspecting some of the renovation sites that municipal inspectors observe from the street. You do not know how frequently or infrequently such inspections occur. You also do not know to what extent it will be possible to undertake renovations so that they are not noticeable from the street. 
and, thus, the probability of detecting any future permit violations would be high. The students assumed, in other words, that pdet escalates based on offense history, and they did so notwithstanding the fact that the facts given them specified that the town authorities used random inspections in enforcing the permit requirement. The student responses suggest that the notion that regulators/law enforcers focus on known past violators is so widely understood and deeply entrenched that past violators might operate as if such a focus existed even in enforcement contexts where, in fact, it does not.

\section{DECLINING SOCIAL SANCTIONS AS AN EXPLANATION OF ESCALATING LEGAL SANCTIONS}

Another possible-and perhaps more promising-explanation for penalty escalation builds on the recognition that most individuals suffer from social sanctions as a result of being publicly identified and punished by the state as a lawbreaker. For example, the aggregate punishment that would be borne by an accountant who is convicted of embezzlement is not limited to the fines or prison sentence he may obtain. He also, in all likelihood, would suffer social and professional stigmatization, with adverse consequences for his material well-being (diminished job opportunities, etc.) and emotional well-being (loss of friends and esteem). ${ }^{51}$ Corporate entities also suffer from nongovernmental sanctions resulting from government detection and punishment of wrongdoing: A company that illegally employs minors may receive only a modest government fine but lose many thousands of dollars in business from disapproving customers, as well as a penalty in the form of reduced stock prices. ${ }^{52}$

Until recently, most law-and-economics scholars have implicitly assumed that the only relevant penalties or sanctions faced by prospective

51. See John R. Lott, Jr., An Attempt at Measuring the Total Monetary Penalty from Drug Convictions: The Importance of an Individual's Reputation, 21 J. LEGAL STUD. 159, 160-61 (1992) (estimating that between forty-nine and sixty percent of the average criminal's pecuniary penalty for an embezzlement, fraud, larceny, or theft conviction is attributable to loss in postconviction earnings (citing John R. Lott, Jr., Do We Punish High Income Criminals Too Heavily?, 30 ECON. INQUIRY 583 (1992))).

52. In a recent empirical study, Cindy Alexander concludes that corporations do suffer from reputational penalties in the form of reduced share price but the magnitude of the reputational penalty tends to be smaller for crimes against unrelated parties (for example, environmental offenses) than for crimes against related parties (for example, defrauding customers, such as the government, in the defense procurement context). Cindy $\mathbf{R}$. Alexander, On the Nature of the Reputational Penalty for Corporate Crime: Evidence, 42 J.L. \& ECON. 489 (1999). But see Anup Agrawal et al., Management Turnover and Governance Changes Following the Revelation of Fraud, 42 J.L. \& ECON. 309 (1999) (questioning the existence of reputational sanctions based on the finding of little systematic evidence that firms suspected or charged with fraud have unusually high turnover among senior managers or directors). 
offenders are legal sanctions, such as fines and imprisonment. ${ }^{53}$ Consistent with this implicit assumption, previous attempts to explain escalation in legal penalties based on offense history have not taken into account extralegal, social sanctions and their possible relevance to an explanation of policies and practices concerning legal sanctions. But social sanctions are important because they form part of the aggregate expected penalty for prospective offenders: For the company contemplating hiring minors, the expected penalty that matters (or should matter) in its decisionmaking is the probability of detection multiplied by the sum of the government sanction for a violator of child labor laws and the social sanction for a violator of child labor laws.

It seems probable that the magnitude of the social sanction for many offenses declines with each successive offense. The reason this is so is that, once someone has been identified as (say) a convicted embezzler, he or she loses most of the "legitimate" opportunities and associations available to people without a record: Citicorp probably is not going to hire a convicted embezzler whether he or she has one or two or more convictions. Similarly, a company with one publicized child labor violation is likely to lose most of its socially concerned customers, but the company probably can retain most of its purely price-conscious customers even if it compiles a record of repeated violations. So also a corporation that is penalized for violating pollution laws once may lose the patronage of all its "green" customers and investors, but other customers and investors may continue to do business with the corporation even if it compiles a string of violations. In other words, in terms of social capital, prospective first-time offenders have the most to lose; repeat offenders with long records have the least to lose. Or to state the point more generally, social sanctions decline based on offense history.

If the preceding analysis is correct, then the government may need to escalate its formal penalties based on offense history in order to ensure that the aggregate expected penalty-the expected social penalty plus the expected government penalty-remains constant for all similar offenses. For example, imagine that the harm from a certain offense equals $\$ 15$ million. The expected social sanction for a first-time offender is $\$ 10$ million, for a second-time offender $\$ 4$ million, for a third-time offender $\$ 2$ million, and for a fourth-time offender $\$ 1$ million. Therefore, for the aggregate expected sanction to equal $\$ 15$ million for each offense, the expected government sanction for a first offense should be $\$ 5$ million, for a second offense $\$ 11$ million, for a third offense $\$ 13$ million, and for a fourth offense $\$ 14$ million. What appears to be escalation in penalties if one focuses only upon legal sanction thus turns out to be part of a practice of 
nonescalation in aggregate expected sanctions, which is precisely the practice that is called for by the most straightforward application of the optimal-deterrence model. Figure 4 illusirates this relationship between legal and extralegal sanctions. L1 represents the expected legal sanction, L2 the expected social sanction, and L3 the expected aggregate sanction (as well as the harm from the violation).

FIGURE 4

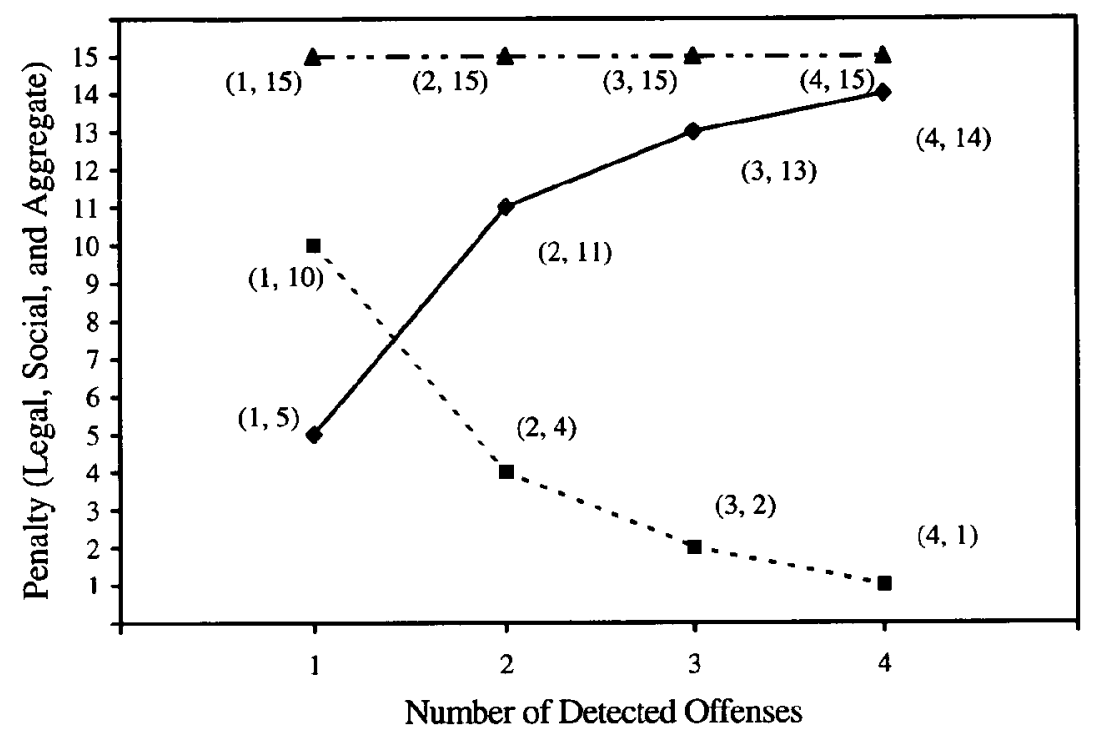

Inclusion of social capital considerations, moreover, may help explain why we generally punish more severely the person who commits a second offense right after having been caught and punished for his or her first offense. As time passes after a first detected offense, the experience of detection and punishment becomes less salient for the individual. But the same also may be true of the broader societal perception of the first offense: That fact fades over time, giving the individual an opportunity to restore his social capital. So, for example, consider the owner of a restaurant that violated food safety codes and was fined by local authorities. One month after receiving the fine, that experience is very salient in his mind, but it is also salient in the community, and so many customers and friends stay away from the restaurant. At that point, the restaurant owner may perceive a high probability of detection for any new food safety violations (because of salience) but he also may perceive that he has relatively little to lose as far 
as social sanctions are concerned. Two years later, the first detected offense may be less salient in his mind, and so he may perceive a lower probability of detection, but he has more to lose: He has rebuilt his reputation and business. If social capital considerations overwhelm the effect of salience on perceived pdet, then it may be necessary for the state, in order to achieve a constant level of deterrence over time, to set higher penalties for the second offense that immediately follows the first than it does for the second offense that occurs a number of years after the first offense.

The preceding analysis is subject to at least two objections. First, it is not obvious that the penalty escalation based on offense history observed in actual settings fits the pattern that would be called for by the analysis. As Figure 4 shows, one would expect that the marginal increases in legal penalties for each subsequent offense would be diminishing because the marginal losses in social capital for each subsequent offense diminish. In other words, legal penalties should jump markedly after the first offense, but then increase only slightly (and ever more slightly) thereafter. There may be some contexts where this pattern obtains, but it is certainly not universally true: As noted above, increases are sometimes observed after the second and third offense that are very substantial..$^{54}$

A second important objection to the preceding analysis is that it assumes that the social sanction does not depend upon-is independent of-the legal sanction. But that assumption may be untenable, particularly for kinds of conduct where the law is playing a significant role in shaping and developing the public's normative evaluation of the conduct. Consider the example of violations of extremely technical water pollution laws by a large oil company: The penalty for the first violation is a $\$ 10,000$ civil fine; for a second violation, the penalty is a $\$ 1$ million criminal penalty. One might expect that some consumers and investors (who after all lack any independent knowledge of water pollution and its consequences) would be guided by the severity of the legal sanction in applying their social sanction to the company; that is, consumers and investors might punish the company more in response to news of the $\$ 1$ million criminal penalty than they would in response to news of a $\$ 10,000$ civil fine. The strength of this objection probably depends on context and, in particular, whether the individuals and entities at issue retain a substantial amount of social capital even after their first or second detected offenses. For example, if a company has only a small set of "green" customers and investors, and all of them deem the company's first violation and civil penalty as proof that the company was not green enough to do business with, then the company would have little to lose, in social sanction terms, from subsequent

54. Supra note 36 (discussing penalty increases after the second offense). 
violations, even if the legal sanctions escalated to much larger criminal fines. ${ }^{55}$

\section{PENALTY EsCALATION, WRONGFULNESS, AND COMPLIANCE}

If the optimal-deterrence framework, even after factoring in the emerging insights of behavioral economics and the role of extralegal sanctions, cannot explain why there is penalty escalation in contexts where the optimal level of deterrence is not maximal, what can? Why is there significant escalation in the context of many regulatory offenses that many thoughtful observers would regard as generally, but not invariably, inefficient from a societal perspective?

This Part sketches a final possible answer, focusing upon how penalty escalation based on offense history might result in greater internalization of a commitment to obey the law. The argument builds on empirical studies that suggest that compliance levels are affected by the law's messages of wrongfulness and nonwrongfulness. ${ }^{56}$ According to the social psychology literature, deterrence models of human decisionmaking do not fully describe how most people think in most contexts. ${ }^{57}$ People sometimes do not obey the law because their calculations indicate that expected penalties exceed expected gain; indeed, people sometimes do not calculate at all, or even have cognizance of probabilities of detection or penalties for noncompliance. Instead, to a significant extent, people obey the law because they have internalized the belief that obeying the law is the right thing to do; they respect the law and want to regard themselves as lawabiding. ${ }^{58}$ And they respect the law because they perceive the law as

55. To my knowledge, none of the published studies of reputational and other extralegal sanctions purports to measure the relationship between marginal increases in legal sanctions between first offenses and second offenses and marginal increases or decreases in the corresponding extralegal sanctions. One impediment in constructing such a study would be the difficulties in measuring extralegal sanctions. A second impediment is that, in order to capture effects of repeat offenses, one would need data over a significant time period. Finally, measurement and data availability problems aside, there may be too few data points in the context of some categories of offenses, particularly regulatory offenses against businesses and other organizations, to draw robust conclusions. See Mark A. Cohen, Empirical Research on the Deterrent Effect of Environmental Monitoring and Enforcement, [2000] 30 Envtl. L. Rep. (Envtl. L. Inst.) 10245 (April 2000) (discussing the failure of studies to compare the loss in stock value to the magnitude of penalties).

56. On the role of the law as an expressive device that shapes preferences and norms, see generally Dan M. Kahan, The Secret Ambition of Deterrence, 113 HARV. L. REV. 413, 419-25 (1999); Dan M. Kahan, Social Meaning and the Economic Analysis of Crime, 27 J. LEGAL STUD. 609 (1998); and Cass R. Sunstein, Law, Economics and Norms: On the Expressive Function of Law, 144 U. PA. L. REV. 2021 (1996).

57. See, e.g., Kyron Huigens, The Dead End of Deterrence and Beyond, 41 WM. \& MARY L. REV. 943, 944 (2000) (discussing critiques of deterrence theory).

58. See, e.g., Robert Cooter, Expressive Law and Economics, 27 J. LEGAL STUD. 585 (1998) (discussing the role of internalization in compliance decisions). 
embodying, as being in tune with, their own conception of what is just and unjust, right and wrong. ${ }^{59}$ When a penalty regime itself characterizes prohibited conduct as not wrongful, people will receive and be influenced by that message, accept the message, and internalize the view that it is not wrong, not morally blameworthy, to disobey the law. Thus, a regime that fails to express the wrongfulness of prohibited conduct must rely solely on the deterrent effect of penalties to induce compliance. By contrast, a penalty regime that does express wrongfulness can rely on the deterrent effect of penalties (to the extent that people are expected penalty/expected gain calculators) and on the respect for the moral authority of the law for compliance (to the extent that people are not expected penalty/expected gain calculators).

This analysis raises the question whether penalty escalation based on offense history functions to express the wrongfulness-wrongfulness in a moral and not merely legal sense-of conduct contrary to law. If escalation serves that function, then escalation may facilitate greater compliance with lower enforcement costs. And escalation may be justified on that basis. ${ }^{60}$

\section{A. The Message of Penalty Escalation and Alternative Penalty Regimes}

To understand the expressive function of penalty escalation based on offense history, it may be helpful to consider again the example of wetlands. The Clean Water Act prohibits landowners from filling wetlands

59. See, e.g., Paul H. RoBinson \& John M. DaRley, JUSTICE, LiabilTY, AND Blame 6 (1995) ("Recent empirical evidence suggests that criminal law's most effective mechanism of compliance is not the threat of sanction; it is the capacity to authoritatively describe the moral and proper rules of conduct."): TOM R. TYLER, WHY PEOPLE OBEY THE LAW 178 (1990) (concluding, based on interviews with Chicago residents, that "normative issues matter. People obey the law because they believe that it is proper to do so.... The image of the person resulting from these findings is one of a person whose attitudes and behavior are influenced to an important degree by social values about what is right and proper"); Marc G. Gertz \& Leroy C. Gould, Fear of Punishment and the Willingness To Engage in Criminal Behavior: A Research Note, $23 \mathrm{~J}$. CRIM. JUST. 377, 383 (1995) (concluding, based on a study of college students, that the primary determinants of criminality were "whether the respondent had ever engaged in similar activities and whether the respondent thought the activity was wrong"); Raymond Paternoster \& Sally Simpson, Sanction Threats and Appeals to Morality: Testing a Rational Choice Model of Corporate Crime, 30 LAW \& SOC'Y REV. 549, 579 (1996) (concluding, based on survey results, that both moral inhibitions and fear of punishment are significant determinants of corporate crime). But see Steven Klepper \& Daniel Nagin, Tax Compliance and Perceptions of the Risks of Detection and Criminal Prosecution, 23 LAW \& SOC'Y REV. 209, 237-38 (1989) ("Not only do taxpayers appear to make calculated decisions, weighing the benefits and costs of noncompliance, .... [but] our results portray an image of an informed, rational taxpayer who structures his noncompliance gambles to keep the risks of detection and criminal prosecution down to acceptable levels.").

60. The possible expressive functions of penalty escalation have received passing attention from Dau-Schmidt. Kenneth G. Dau-Schmidt, An Economic Analysis of the Criminal Law as a Preference-Shaping Policy, 1990 DUKE L.J. 1 (hinting at but not developing the argument that penalty escalation may serve some expressive function). 
without a permit. ${ }^{61}$ To simplify matters, assume that (1) only two sanctions are possible for unpermitted filling of wetlands: a moderate sanction of a $\$ 10,000$ fine and a severe sanction of a $\$ 100,000$ fine and one year in prison; and (2) the maximum number of violations by any landowner is two. At least four penalty regimes are possible: (1) a regime of declining penalties based on offense history, in which the first detected offense would garner a severe sanction and the second offense would garner a moderate sanction; (2) a regime of constant moderate sanctions, in which first and second offenses would garner a moderate sanction; (3) a regime of constant severe sanctions, in which first and second offenses would garner a severe sanction; and (4) a regime of escalating penalties based on offense history, in which the first offense would garner a moderate sanction and the second offense would garner a severe sanction.

The first regime-the declining penalty regime-arguably expresses the message that the government (and by extension society) does not regard wetlands violations as truly wrongful conduct. In the vernacular or popular understanding, the notion that certain conduct is morally wrong and the notion that the conduct must or should be tolerated are inconsistent; if conduct is wrong, it simply should not be tolerated. ${ }^{62}$ By publicly announcing a reduction in the penalty that previously failed to deter a violation, the declining penalty regime seems to accept, even invite, further violations. ${ }^{63}$ And after repeat violations do occur, the regime seems to reward rather than punish the repeat violator for having determinedly flouted the authority of the wetlands regulations and the law in general. ${ }^{64}$ The second regime- the constant moderate sanctions regime - also fails to express the wrongfulness of unpermitted filling of wetlands. A constant moderate sanctions regime announces the maintenance of a penalty level that has already proven inadequate to deter first offenses and, in that sense,

61. 33 U.S.C. $\$ 1344$ (1994).

62. See Robert Cooter, Prices and Sanctions, 84 Colum. L. REv. 1523, 1532 (1984) (suggesting that when the law communicates that conduct is truly forbidden-as opposed to communicating that the conduct is permissible as long as a tax or price is paid-people will comply with the law on normative or moral grounds even if the expected penalty is mistakenly set too low so that it does not exceed the expected benefits of violations).

63. Of course, if the public generally understands probabilities of detection as escalating, and if they think in expected penalty terms, then they would understand that a declining penalties regime may entail constant or even escalating expected perialties. But, unlike formally applicable penalties, which appear in published statutes and codes, probabilities of detection are not highly visible to the public and thus probably do not figure as heavily in the expressive messages communicated by the law to the public. Cf. Alon Harel \& Uzi Segal, Criminal Law and Behavioral Law and Economics: Observations on the Neglected Role of Uncertainty in Deterring Crime, 1 AM. L. \& ECON. REv. 276 (1999) (suggesting that disparities among offenders in probabilities of detection do not implicate or offend popular intuitions, as compared to disparities in formal sentences).

64. Cf. ANDREW VON HIRSCH, DONG JUSTICE: THE CHOICE OF PUNISHMENTS 85 (1976) (arguing that repeat offenders are more culpable because they "persisted in the behavior after having been forcefully censured for it through [their] prior punishment"). 
also countenances repeat violations. Such a regime also does not punish the determined flouting of the law.

By contrast, the third regime-the constant severe sanctions regimedoes express a message of the wrongfulness of wetlands violations. By adopting severe sanctions from the start, the legal regime communicates its condemnation of wetlands violations, even if those severe sanctions fail to deter a few intransigent landowners. Jailing landowners for a year for all wetlands violations would, without doubt, convey a strong wrongfulness message. ${ }^{65}$

The fourth regime-the escalating penalty regime-expresses a similar message. In an escalating penalty regime, it is true that the first-time offender does not receive a severe sanction. But the fact that a severe sanction will be necessary for deterrence of any given individual or entity is not obvious until after the first violation, and once that fact is obvious, the regime does shift to a severe sanction, communicating its condemnation and intolerance of unpermitted filling of wetlands. The "break" given firsttime violators can be understood-I think generally is understood-as morally appropriate because the violator may have simply made a mistake or acted foolishly out of impulse, rather than having determinedly flouted the moral authority of the laws he or she broke and of "the law" generally.

From the perspective of communicating wrongfulness, then, both a regime of constant severe sanctions and a regime of escalating sanctions are desirable. But the former may not be feasible, either because it seems, on mercy and empathy grounds, simply too harsh toward unknowing or foolish first-time offenders; or because, to return to the arguments of Polinsky and Rubinfeld ${ }^{66}$ it is too expensive for the government to maintain and enforce generally applicable severe sanctions and more economical to limit such sanctions to repeat offenders; or because, to return to the arguments of Rubinstein and Chu, Hu, and Huang, ${ }^{67}$ the risk of mistake in prosecutions of repeat offenses may be lower than the risk for first offenses.

One notable objection to the preceding analysis pertains to proof. The preceding analysis relies on two propositions that are, fundamentally,

65. This message would be clear only if the public had some criteria by which to categorize sanctions as severe, as opposed to moderate. Cf. Elizabeth S. Anderson \& Richard H. Pildes, Expressive Theories of Law: A General Restatement, 148 U. PA. L. REV. 1503, 1525 (2000) (arguing that "[a]lthough [expressive] meanings do not actually have to be recognized by the community, they have to be recognizable by it, if people were to exercise enough interpretive selfscrutiny. This is the sense in which expressive meanings are public constructions"). Most people probably do have very rough criteria for what makes a sanction more or less severe, but they nonetheless might have difficulties categorizing particular sanctions, and different subpopulations of the public might have different views as to which particular sanctions are severe or moderate. My example elides this difficulty because, from the perspective of almost everyone, a jail sentence for a wetlands violation would be regarded as a severe sanction.

66. See supra note 29 and accompanying text.

67. See supra notes 33-34 and accompanying text. 
empirical-first, that penalty escalation and nonescalation send different messages about law's moral content, and second, that these different messages translate into different levels of compliance. But there is no direct data supporting either proposition. Ideally, one would like to test these propositions by comparing the perceptions and compliance decisions of populations exposed to penalty escalation and penalty nonescalation regimes. It is possible that empirical study will disprove my speculative account, and demonstrate that the moral credibility of penalty regimes does not depend on penalty escalation based on offense history, or that any moral credibility related to escalation does not substantially affect compliance.

Another possible objection concerns the kind of "wrongfulness" message penalty escalation might be understood as sending. One might argue that escalating penalties do not label certain conduct as morally wrongful so much as they label disobedience and defiance of the legal system in general as wrongful. Indeed, where enhancements in penalties may be based on a history of dissimilar past violations, the most straightforward message of escalation may be that it is wrong to flout the authority of the law. But where enhancements in penalties are triggered only by a history of similar past violations, the expressive message would seem to be focused at least in part on the nature of the particular conduct at issue.$^{68}$ In the regulatory context, most penalty enhancements are based on similar past violations. The EPA, for example, does not (and probably lawfully could not) enhance penalties imposed upon a company on the grounds that the company had a history of labor and securities law violations.

\section{B. The Distinction Between Reinforcing and Creating a Perception of Wrongfulness}

The compliance benefits of penalty escalation may not be uniform for all categories of offenses. Notably, many people probably would regard "traditional" violent crimes such as assault as wrong even if the penalty regime did not reinforce that message of wrongfulness by means of penalty escalation. The existence of penalty escalation for such offenses may reinforce, and in that sense strengthen, the general perception that such violent offenses are wrongful. But given the many non-escalation-related reasons for the general perception that violent crime is wrongful, it is likely that penalty escalation plays only a modest role and, again, only as a

68. The qualification "in part" is important, since penalty escalation can carry (and likely often does) multiple messages. For example, where an agency such as the EPA imposes more severe penalties for repeated infractions of pollution control laws, the agency sends the message both that it is wrong to pollute in violation of law and that it is wrong to flout the authority of the EPA. 
reinforcement. To state the point differently, few people need three-strikesand-you're-out laws to know that murder or rape or assault is wrong.

In other contexts, however, it is less clear that the societal consensus regarding the wrongfulness of prohibited conduct is so broad and deeply entrenched that the presence or absence of penalty escalation makes little difference. This is arguably true of nonviolent property crime, as well as "victimless" crimes such as drug possession and prostitution. It also may be true of regulatory or public welfare offenses, such as violations of labor and environmental regulations. Some, maybe even the majority of people, would regard the filling of wetlands without a permit as simply, plainly wrong, even if the legal system did not clearly label and treat such conduct as plainly wrongful by imposing escalating penalties. But some people probably would not be predisposed to regard such conduct as wrongful, and for such people escalating penalties may play an important role in not merely reinforcing, but rather creating, their perception of the conduct in question as wrongful. ${ }^{69}$

\section{A Normative Evaluation of Penalty Escalation as a Means of Reinforcing and Creating Perceptions of Wrongfulness}

Is it a good thing that penalty escalation reinforces or creates perceptions of wrongfulness (assuming it does)? Certainly, with respect to conduct that society wishes to deter maximally, conduct that is thought to be socially undesirable in all cases, the answer is yes. In such cases, penalty escalation deters socially undesirable conduct - conduct that the legal system might be able to deter otherwise only with a significant additional expenditure of enforcement resources. Thus, with respect to offenses for which the optimal level of deterrence is maximal, penalty escalation based on offense history makes sense both as a deterrence-enhancing device (as discussed in Part II) and as an expressive device.

69. The distinction between the reinforcement and the creation of a perception of wrongfulness may help to illuminate the relationship between the analysis developed in this Part and that developed in Part IV. Where a particular kind of conduct is not yet widely regarded as wrongful, extralegal sanctions may not be a significant part of the total sanctions borne by detected violators, and so the justification for escalating sanctions set out in Part IV may not be applicable. At the same time, it is precisely in such cases that escalation can serve an important expressive function by creating a broad-based perception of wrongfulness. For example, the extralegal sanctions borne by a development company that commits repeated violations of wetlands laws may not be significant because the customers and local officials with whom the company does business may not yet regard wetland violations as truly wrongful, and hence may not impose any extralegal sanctions on the company. At the same time, escalation may be important in communicating to the individuals who make up the company-as well as to those individuals with whom the company does business-the message that the state regards violations of wetlands laws as truly wrongful. As a result, some of those individuals may begin to reevaluate their moral understanding of violations of wetlands laws. 
With respect to offenses for which optimal deterrence is less than maximal deterrence, the desirability of penalty escalation as an expressive device is more contestable. Consider, for example, prohibitions against filling wetlands. Assume that violations of the wetlands regulations are efficient in $90 \%$ of the cases and inefficient in $10 \%$ of the cases, and that all people make compliance decisions based only on wrongfulness grounds. If all people came to comply with wetlands regulations because the law labels wetlands destruction as simply wrong, then there would be a high level of compliance with respect to inefficient violations but also with respect to efficient violations. A preferable enforcement regime would produce high levels of compliance only with respect to the inefficient violation cases.

Moreover, not all people will respond to expressive messages about wrongfulness; to some extent, people do make calculations as to expected penalties in conformity with the neoclassical economic model of human decisionmaking. To the extent that potential violators are rational calculators, and to the extent that the offenses at issue are those for which optimal deterrence is not maximal deterrence, an escalation regime may produce inefficient compliance by increasing penalties for repeat offenders when the logic of the optimal-deterrence model would not prescribe escalation. Thus, with respect to offenses for which optimal deterrence is not maximal deterrence, penalty escalation may induce inefficient compliance on the part both of people who operate on the basis of wrongfulness/normative considerations and of those who operate as rational expected benefit/penalty calculators. ${ }^{70}$

That this is so does not mean that penalty escalation based on offense history is, overall, a bad thing, at least as long as the benefits of forgone inefficient violations and conserved enforcement expenditures outweigh the costs of forgone inefficient violations. It may be impossible to structure an enforcement regime to induce compliance only when it is efficient, or, alternatively, such an enforcement regime may be theoretically possible but too cumbersome and expensive to implement. Thus, because it induces compliance by expressing the wrongfulness of violations such as

70. There is another possible cost to utilizing penalty escalation to convince the populace that certain conduct is wrongful, even though it has not been traditionally regarded as such, when the optimal deterrence-level is not maximal. As Robinson and Darley have argued, the use of the law to label as wrongful conduct that is not popularly conceived as such may undermine the moral legitimacy of the law and hence reduce compliance even with respect to core, traditional offenses for which a consensus as to their wrongfulness has long existed. See ROBINSON \& DARLEX, supra note 59, at 7 ("The legal system that the community perceives as unjustly criminalizing certain conduct is one that is likely to cause the society governed by those laws to lose faith in the system-not only in the specific laws that lead to the unjust result, but in the entire code and criminal justice system enforcing that code.") This cost may be only transitory, as Robinson and Darley themselves admit. Once the law shapes popular understandings of the wrongfulness of certain conduct (assuming it eventually can), the tension between the law and community values will disappear and so too the threat of the delegitimization of the legal system. 
unpermitted wetlands filling, penalty escalation may be the best means to maximize social welfare in the second-best world we inhabit.

\section{CONCLUSION}

Particularly in the context of regulatory offenses, such as violations of environmental regulations, the phenomenon of escalating penalties for repeat offenders tests the explanatory limits of economics. Contrary to the assumptions in the existing literature, probabilities of detection increase for repeat offenders. As a result, the optimal-deterrence model dictates declining, rather than escalating, penalties for repeat offenders. Mining the insights of the emerging behavioral economics literature only makes matters worse, because the salience and optimism biases both support declining penalties as well. The gap between economic theory and actual practice is thus much wider than has been previously recognized. This Article has identified two alternative conceptions of the role of legal penalties that may help to bridge that gap: legal penalties as supplements to extralegal sanctions and as expressive devices that help shape perceptions of moral wrongfulness. Further exploration of these alternative conceptions of legal penalties may be the most promising route to solving the puzzle of escalating penalties once and for all. 
